University of Nebraska - Lincoln

DigitalCommons@University of Nebraska - Lincoln

2005

\title{
Major and trace element composition of copiapite-group minerals and coexisting water from the Richmond mine, Iron Mountain, California
}

\author{
Heather E. Jamieson \\ Queen's University, Department of Geological Sciences and Geological Engineering \\ Clare Robinson \\ Queen's University, Department of Geological Sciences and Geological Engineering \\ Charles N. Alpers \\ U.S. Geological Survey \\ R. Blaine McCleskey \\ U.S. Geological Survey \\ D. Kirk Nordstrom \\ U.S. Geological Survey \\ See next page for additional authors \\ Follow this and additional works at: https://digitalcommons.unl.edu/usgsrye \\ Part of the Geochemistry Commons
}

Jamieson, Heather E.; Robinson, Clare; Alpers, Charles N.; McCleskey, R. Blaine; Nordstrom, D. Kirk; and Peterson, Ronald C., "Major and trace element composition of copiapite-group minerals and coexisting water from the Richmond mine, Iron Mountain, California" (2005). Geochemistry of Sulfate Minerals: A Tribute to Robert O. Rye. 1.

https://digitalcommons.unl.edu/usgsrye/1

This Article is brought to you for free and open access by the US Geological Survey at DigitalCommons@University of Nebraska - Lincoln. It has been accepted for inclusion in Geochemistry of Sulfate Minerals: A Tribute to Robert O. Rye by an authorized administrator of DigitalCommons@University of Nebraska - Lincoln. 
Authors

Heather E. Jamieson, Clare Robinson, Charles N. Alpers, R. Blaine McCleskey, D. Kirk Nordstrom, and Ronald C. Peterson 


\title{
Major and trace element composition of copiapite-group minerals and coexisting water from the Richmond mine, Iron Mountain, California
}

\author{
Heather E. Jamieson ${ }^{\mathrm{a}, *}$, Clare Robinson ${ }^{\mathrm{a}}$, Charles N. Alpers ${ }^{\mathrm{b}}$, R. Blaine McCleskey ${ }^{\mathrm{c}}$ \\ D. Kirk Nordstrom ${ }^{\mathrm{c}}$, Ronald C. Peterson ${ }^{\mathrm{a}}$ \\ ${ }^{a}$ Queen's University, Department of Geological Sciences and Geological Engineering, Kingston, Canada K7L 3N6 \\ ${ }^{\mathrm{b}}$ U.S. Geological Survey, Placer Hall, 6000 J Street, Sacramento, CA 95819, USA \\ ${ }^{\mathrm{c}}$ U.S. Geological Survey, 3215 Marine Street, Suite E-127, Boulder, CO 80303, USA
}

Accepted 1 June 2004

\begin{abstract}
Copiapite-group minerals of the general formula $A R_{4}\left(\mathrm{SO}_{4}\right)_{6}(\mathrm{OH})_{2} \cdot n \mathrm{H}_{2} \mathrm{O}$, where $A$ is predominantly $\mathrm{Mg}$, $\mathrm{Fe}^{2+}$, or $0.67 \mathrm{Al}^{3+}$, $R$ is predominantly $\mathrm{Fe}^{3+}$, and $n$ is typically 20, are among several secondary hydrous Fe sulfates occurring in the inactive mine workings of the massive sulfide deposit at Iron Mountain, CA, a USEPA Superfund site that produces extremely acidic drainage. Samples of copiapite-group minerals, some with coexisting water, were collected from the Richmond mine. Approximately 200 $\mathrm{mL}$ of brownish pore water with a $\mathrm{pH}$ of -0.9 were extracted through centrifugation from a 10-L sample of moist copiapite-group minerals taken from pyritic muck piles. The pore water is extremely rich in ferric iron $\left(\mathrm{Fe}^{3+}=149 \mathrm{~g} \mathrm{~L}^{-1}, \mathrm{Fe}_{\mathrm{T}}=162 \mathrm{~g} \mathrm{~L}^{-1}\right)$ and has a density of $1.52 \mathrm{~g} \mathrm{~mL}^{-1}$. The composition of the pore water is interpreted in the context of published phase relations in the $\mathrm{Fe}_{2} \mathrm{O}_{3}-$ $\mathrm{SO}_{3}-\mathrm{H}_{2} \mathrm{O}$ system and previous work on the chemistry of extremely acid mine waters and associated minerals in the Richmond mine. Two distinct members of the copiapite mineral group were identified in the samples with coexisting water: (1) abundant magnesiocopiapite consisting of platy crystals 10 to $50 \mu \mathrm{m}$ and (2) minor aluminocopiapite present as smaller platy crystals that form spheroidal aggregates. The average composition $(n=5)$ of the magnesiocopiapite is $\left(\mathrm{Mg}_{0.90} \mathrm{Fe}_{0.17}^{2+} \mathrm{Zn}_{0.02-}\right.$ $\left.\mathrm{Cu}_{0.01}\right)_{\sum 1.10}\left(\mathrm{Fe}_{3.83}^{3+} \mathrm{Al}_{0.09}\right)_{\sum 3.92}\left(\mathrm{SO}_{4}\right)_{6.00}(\mathrm{OH})_{1.96} \cdot 20 \mathrm{H}_{2} \mathrm{O}$. Bulk compositions determined by digestion and wet-chemical analysis are consistent with the microanalytical results. These results suggest that magnesiocopiapite is the least soluble member of the copiapite group under the prevailing conditions. Micro-PIXE analysis indicates that the copiapite-group minerals in this sample sequester $\mathrm{Zn}$ (average $1420 \mathrm{ppm}$ ), with lesser amounts of $\mathrm{Cu}$ (average $270 \mathrm{ppm}$ ) and As (average $64 \mathrm{ppm}$ ).
\end{abstract}

(C) 2004 Elsevier B.V. All rights reserved.

Keywords: Copiapite group; Fe sulfates; Acid mine drainage; Trace elements

* Corresponding author. Tel.: +1 613533 6181; fax: +1 6135336592.

E-mail address: jamieson@geol.queensu.ca (H.E. Jamieson).

0009-2541/\$ - see front matter (C) 2004 Elsevier B.V. All rights reserved. doi:10.1016/j.chemgeo.2004.10.001 


\section{Introduction}

Conditions at the inactive Richmond mine in northern California are optimal for the production of extremely acid, sulfate-rich, and metal-rich water (Nordstrom and Alpers, 1995, 1999a). Prior to treatment, water flowing from the Richmond mine has $\mathrm{pH}$ values near 0.5 and has total dissolved solids (TDS) concentrations of about $200 \mathrm{~g} \mathrm{~L}^{-1}$. Waters dripping from Fe-sulfate stalactites within the Richmond mine have $\mathrm{pH}$ values as low as -3.6 and TDS concentrations approaching $1 \mathrm{~kg} \mathrm{~L}^{-1}$, which are among the most acidic and concentrated waters reported in the world (Nordstrom and Alpers, 1999a; Nordstrom et al., 2000).

Iron Mountain is in Shasta County, approximately $15 \mathrm{~km}$ northwest of Redding, along the southeastern edge of the Klamath Mountains, CA. Gold, Ag, Cu, $\mathrm{Zn}, \mathrm{Fe}$, and pyrite (for sulfuric acid production) were mined at Iron Mountain at various times over an interval of about 100 years. Mining began in the early 1860s and terminated with open-pit mining of pyrite in 1962. The massive sulfide deposits at Iron Mountain are Devonian, and the mines are the largest historical producers of copper in the State of California (Kinkel et al., 1956).

The Iron Mountain site possesses all of the characteristics required to maximize sulfide oxidation and acid generation. These include (1) ore with a high pyrite content (95-98\%); (2) low acid neutralization capacity of the hydrothermally altered metavolcanic host rock; (3) ready availability of gaseous oxygen and water in porous and unsaturated conditions of the mine workings; (4) the presence of $\mathrm{Fe}$ - and Soxidizing bacteria (e.g., Edwards et al., 2000; Robbins et al., 2000); and (5) elevated temperatures observed at $28-47{ }^{\circ} \mathrm{C}$ and estimated to be as high as $60-70{ }^{\circ} \mathrm{C}$ caused by exothermic oxidation of pyrite. The heating enhances the evaporation rate of subsurface mine waters, concentrating the acidity, metals, and sulfate in the water and leading to the formation of acid, hydrous Fe-sulfate minerals (Nordstrom and Alpers, 1995, 1999a).

Within the underground workings of the Richmond mine at Iron Mountain, abundant Fe-sulfate efflorescences form through oxidation and evaporation of acid mine waters. The repeated precipitation and dissolution of these secondary sulfate minerals have been identified as significant contributing factors to extremely poor water quality at Iron Mountain (Alpers et al., 1992, 1994a, 2003; Nordstrom and Alpers, 1999a; Jamieson et al., 1999). These soluble minerals store $\mathrm{Fe}, \mathrm{SO}_{4}$, potentially hazardous elements, such as $\mathrm{As}, \mathrm{Cd}, \mathrm{Cu}$, and $\mathrm{Zn}$, as well as acidity and $\mathrm{Fe}^{3+}$ (an oxidant) during dry seasons and release them during wet seasons. This cycle results in seasonal variations in water quality, adversely affecting surrounding ecosystems (Alpers et al., 1994a). The sudden increase in dissolved metals after rainfall events (the "first flush" phenomenon) has been noted elsewhere and has been attributed to the dissolution of soluble metal-sulfate salts (e.g., see Bayless and Olyphant, 1993; Jambor et al., 2000 and references therein).

The role of Fe-sulfate minerals in the partitioning of metals from acid mine waters is not well understood, partly because very few well-characterized field samples and coexisting waters have been documented. The Richmond mine is an ideal site at which to study secondary sulfates because the minerals are abundant and coarsely crystalline compared with those at other sites (Alpers et al., 1994a; Jamieson et al., 1999). The site also provides a rare opportunity to sample minerals with their coexisting water (Alpers et al., 1989, 1994a; Nordstrom and Alpers, 1999a; Nordstrom et al., 2000; Robinson et al., 2000a,b).

This study is a detailed mineralogical characterization of copiapite-group minerals of the general formula $A R_{4}^{3+}\left(\mathrm{SO}_{4}\right)_{6}(\mathrm{OH})_{2} \cdot n \mathrm{H}_{2} \mathrm{O}$, where $A$ is predominantly $\mathrm{Mg}, \mathrm{Fe}^{2+}, \mathrm{Zn}, \mathrm{Al}$, or $\mathrm{Fe}^{3+}, R$ is mainly $\mathrm{Fe}^{3+}$ but may be $\mathrm{Al}$, and $n$ ranges from 18 to 20 but is most commonly 20 (Mandarino, 1999). The mineral copiapite sensu stricto has $A=\mathrm{Fe}^{2+}$ and $R=\mathrm{Fe}^{3+}$, making it a mixed ferrous-ferric sulfate mineral. Copiapite-group minerals are relatively common in oxidized sulfide deposits and mine-waste environments (Jambor et al., 2000). A large (10 L) sample of massive copiapite-group minerals was collected, with coexisting pore water, from the Richmond mine in July 1998. Both solid and liquid fractions of the sample were analyzed by a variety of methods to determine the conditions under which minerals of the copiapite group form and how their precipitation and dissolution may influence mine-water chemistry. To our knowledge, this is the first report of the geochemistry of copiapite-group minerals and the waters with which they are associated in a field setting. 


\section{Minerals of the copiapite group}

The copiapite-group minerals are one of the more common Fe-sulfate groups (Berry, 1947; Nordstrom, 1982; Jambor et al., 2000). Copiapite-group minerals generally occur in the oxidation zone of sulfidic iron ore and massive sulfide deposits. The minerals form as canary yellow to orange, tabular crystals in loose aggregations, and crusts on the surfaces of sulfide minerals in mine workings and in mine waste and tailings piles, especially in areas protected from rainstorms and transient surface flows. Copiapite-group minerals may occur as efflorescent salts near acidic drainage streams (Nordstrom and Alpers, 1999b) and in association with coal seams (McCaughey, 1917; Zodrow, 1980; Bayless and Olyphant, 1993; Cravotta, 1994; Jambor, 1994). Copiapite-group minerals are commonly associated with other sulfate minerals, such as $\mathrm{Fe}^{2+}$ sulfates (e.g., melanterite, szomolnokite), other mixed divalent-trivalent $\mathrm{Fe}$ sulfates (römerite, voltaite), and ferric sulfates or ferric oxyhydroxides (Merwin and Posnjak, 1937; Bandy, 1938; Bayless and Olyphant, 1993; Jambor, 1994; Alpers et al., 1994b; Jambor et al., 2000). Table 1 lists idealized formulae of the most common Fe-sulfate minerals at the Richmond mine. Some authors have reported paragenetic sequences observed in the field and the laboratory, in which copiapite-group minerals occupy an intermediate position between the $\mathrm{Fe}^{2+}$ sulfates that form directly from pyrite oxidation and later-formed $\mathrm{Fe}^{3+}$ sulfates (e.g., see Bandy, 1938; Nordstrom and

Table 1

Some Fe sulfates from the Richmond mine

\begin{tabular}{ll}
\hline Mineral & Ideal formula \\
\hline $\begin{array}{l}\text { Melanterite } \\
\text { Szomolnokite }\end{array}$ & $\mathrm{Fe}^{2+} \mathrm{SO}_{4} \cdot 7 \mathrm{H}_{2} \mathrm{O}$ \\
$\mathrm{Fe}^{2+}-\mathrm{Fe}^{3+}$ & \\
Copiapite & \\
Römerite & $\mathrm{Fe}_{4} \cdot \mathrm{H}_{2} \mathrm{O}$ \\
Voltaite & $\mathrm{Fe}^{2+} \mathrm{Fe}_{4}^{3+}\left(\mathrm{SO}_{4}\right)_{6}(\mathrm{OH})_{2} \cdot 20 \mathrm{H}_{2} \mathrm{O}$ \\
$\begin{array}{l}\mathrm{Fe}^{3+} \mathrm{Fe}_{2}^{3+}\left(\mathrm{SO}_{4}\right)_{4} \cdot 14 \mathrm{H}_{2} \mathrm{O} \\
\text { Coquimbite } \\
\text { Rhomboclase }\end{array}$ & $\mathrm{K}_{2} \mathrm{Fe}_{5}^{2+} \mathrm{Fe}_{4}^{3+}\left(\mathrm{SO}_{4}\right)_{12} \cdot 18 \mathrm{H}_{2} \mathrm{O}$ \\
Jarosite & \\
\hline & $\mathrm{Fe}_{2}^{3+}\left(\mathrm{SO}_{4}\right)_{3} \cdot 9 \mathrm{H}_{2} \mathrm{O}$ \\
\hline & $\mathrm{HFe}^{3+}\left(\mathrm{SO}_{4}\right)_{2} \cdot 4 \mathrm{H}_{2} \mathrm{O}$ \\
$\mathrm{KFe}_{3}^{3+}\left(\mathrm{SO}_{4}\right)_{2}(\mathrm{OH})_{6}$
\end{tabular}

Table 2

Minerals of the copiapite group

\begin{tabular}{ll}
\hline Mineral & Ideal formula \\
\hline Copiapite & $\mathrm{Fe}^{2+} \mathrm{Fe}_{4}^{3+}\left(\mathrm{SO}_{4}\right)_{6}(\mathrm{OH})_{2} \cdot 20 \mathrm{H}_{2} \mathrm{O}$ \\
Magnesiocopiapite & $\mathrm{MgFe}_{4}^{3+}\left(\mathrm{SO}_{4}\right)_{6}(\mathrm{OH})_{2} \cdot 20 \mathrm{H}_{2} \mathrm{O}$ \\
Cuprocopiapite & $\mathrm{CuFe}_{4}^{3+}\left(\mathrm{SO}_{4}\right)_{6}(\mathrm{OH})_{2} \cdot 20 \mathrm{H}_{2} \mathrm{O}$ \\
Calciocopiapite & $\mathrm{CaFe}_{4}^{3+}\left(\mathrm{SO}_{4}\right)_{6}(\mathrm{OH})_{2} \cdot 20 \mathrm{H}_{2} \mathrm{O}$ \\
Zincocopiapite & $\mathrm{ZnFe}_{4}^{3+}\left(\mathrm{SO}_{4}\right)_{6}(\mathrm{OH})_{2} \cdot 20 \mathrm{H}_{2} \mathrm{O}$ \\
Ferricopiapite & $\mathrm{Fe}_{2 / 3}^{3+} \mathrm{Fe}_{4}^{3+}\left(\mathrm{SO}_{4}\right)_{6}(\mathrm{OH})_{2} \cdot 20 \mathrm{H}_{2} \mathrm{O}$ \\
Aluminocopiapite & $\mathrm{Al}_{2 / 3} \mathrm{Fe}_{4}^{3+}\left(\mathrm{SO}_{4}\right)_{6}(\mathrm{OH})_{2} \cdot 20 \mathrm{H}_{2} \mathrm{O}$ \\
\hline
\end{tabular}

Ideal formulae from Mandarino (1999).

Alpers, 1999b; Jambor et al., 2000, and references therein).

Copiapite was first described as a mineral and analyzed by Rose (1833) and later named by Haidinger (1845) after Copiapo, Chile. Bandy (1938) is credited with some of the earlier ideas concerning the conditions of formation of the mineral from the oxidation of pyritic ores. Berry (1947) chemically analyzed 42 copiapite samples from different countries and determined that $A$ may be one or more of the elements $\mathrm{Na}, \mathrm{K}, \mathrm{Ca}, \mathrm{Cu}$, $\mathrm{Fe}^{2+}, \mathrm{Mn}, \mathrm{Mg}, \mathrm{Zn}, \mathrm{Al}, \mathrm{Fe}^{3+}$, and $R$ is mainly $\mathrm{Fe}^{3+}$ but may be $\mathrm{Al}^{3+}$. Table 2 lists the seven minerals of the copiapite group with their corresponding formulae.

Copiapite-group minerals are triclinic and have a complex structure of multiple chains built by metalcontaining polyhedra and $\mathrm{SO}_{4}$ groups. Three notable features in the atomic arrangement of the copiapite group of minerals are (1) chains formed by $\mathrm{SO}_{4}$ tetrahedra and $R^{3+}(\mathrm{OH})\left(\mathrm{H}_{2} \mathrm{O}\right)_{2} \mathrm{O}_{3}$ octahedra, (2) isolated $A^{2+}\left(\mathrm{H}_{2} \mathrm{O}\right)_{6}$ octahedra at the center of the cell, and (3) "free" water molecules that are not linked directly to cations and that contribute to a complex arrangement of hydrogen bonds (Fanfani et al., 1973; Hawthorne et al., 2000). Although the water limit of the copiapite structure is 20 molecules per unit cell, the presence of six "free" water molecules accommodates partial dehydration without significant disruption to the framework of the mineral (Süsse, 1972; Fanfani et al., 1973; Zodrow, 1980).

Because the space group of copiapite is $\mathrm{P} \overline{1}$ and the cell content is one copiapite formula unit, the $A$ cation must occupy the central position in the cell, assuming a fully ordered atomic arrangement. If the local $\mathrm{O} / \mathrm{A}$ 
ratio is equal to 1.0 (the most common value according to Berry, 1947), where O represents +2 (one oxygen equivalent) and $A=\Sigma$ (cationic charge×occupancy of the cation), then the $A$ position is completely filled when a divalent cation is present. When a trivalent cation occupies the $A$ site, the occupancy is only $2 / 3$, forming copiapite-group minerals with cation vacancies. Hawthorne et al. (2000) have suggested an alternative model without vacancies and with charge balance maintained by a decrease in $\mathrm{H}^{+}$. The $\mathrm{O} / A$ ratios differing from a value of 1.0 can be explained from a structural point of view, assuming that a change of $\mathrm{OH}^{-} \leftrightarrow \mathrm{H}_{2} \mathrm{O}$ can occur in the structure without significantly affecting the atomic structure (Fanfani et al., 1973).

On the basis of the principle of electrostatic valence, cations of lower charge $\left(\mathrm{Ca}^{2+}, \mathrm{Cu}^{2+}, \mathrm{Fe}^{2+}\right.$, $\mathrm{Mg}^{2+}$, or $\mathrm{Zn}^{2+}$ ) should occupy the $A$ site in preference to cations of a higher charge $\left(\mathrm{Al}^{3+}\right.$ or $\mathrm{Fe}^{3+}$; Bayliss and Atencio, 1985). Mutual substitution of divalent cations occurs because the coordination polyhedron is weakly bonded with the rest of the structural chain. This weak connection also allows for the $\mathrm{Al}-\mathrm{Fe}^{3+}$ substitution that occurs preferentially in $A\left(\mathrm{H}_{2} \mathrm{O}\right)_{6}$ isolated octahedra in ferricopiapite (Fanfani et al., 1973) and in coquimbite (Fang and Robinson, 1970). The diverse chemical composition and the arrangement of water molecules within the structure of various copiapite-group minerals account for the differences observed in the refractive indices and atomic coordinates (Posnjak and Merwin, 1922; Merwin and Posnjak, 1937; Bandy, 1938; Berry, 1947; Fanfani et al., 1973; Zodrow, 1980, Bayliss and Atencio, 1985). The basic topology is the same for the different copiapite-group minerals, but the atomic coordinates are significantly different for all of the atoms. The main change occurs in the orientation of the $A$ octahedron and the location of water molecules between the chains. Average bond lengths vary depending on which element(s) has substituted into the polyhedron (Bayliss and Atencio, 1985). For example, when $\mathrm{Al}$ occupies the $A$ site, the average Al-O bond length is $1.93 \AA$ (Fanfani et al., 1973). If $\mathrm{Mg}$ is in the $A$ position, the average $\mathrm{Mg}-\mathrm{O}$ bond length is $2.07 \AA$ (Süsse, 1972). These average bond lengths increase as the result of the substitution of elements with larger atomic radii $\left(\mathrm{Ca}^{2+}, \mathrm{Fe}^{2+}, \mathrm{Zn}^{2+}\right)$, and they decrease for the occupancy of those with relatively smaller atomic radii $\left(\mathrm{Cu}^{2+}, \mathrm{Mg}^{2+}, \mathrm{Fe}^{3+}\right.$, $\mathrm{Al}^{3+}$; Bayliss and Atencio, 1985). These displacements affect the system of hydrogen bonding, which differs noticeably between the ferricopiapite $\left(\mathrm{Fe}^{3+}\right)$ and magnesiocopiapite $\left(\mathrm{Mg}^{2+}\right)$ species.

Few chemical analyses of copiapite minerals from mine-waste sites are available probably because of the difficulties related to the fine-grained and fragile nature of the mineral and its intergrowth with other species. Compositions reported from other environments, such as hot springs and coal deposits, suggest extensive mutual substitution of $\mathrm{Mg}-\mathrm{Fe}^{2+}-\mathrm{Fe}^{3+}-\mathrm{Al}$ (Jambor et al., 2000). Compositions close to endmember cuprocopiapite and zincocopiapite have also been reported (Palache et al., 1951; Perroud et al., 1987).

Experiments by Posnjak and Merwin (1922) in the system $\mathrm{Fe}_{2} \mathrm{O}_{3}-\mathrm{SO}_{3}-\mathrm{H}_{2} \mathrm{O}$ from 50 to $200{ }^{\circ} \mathrm{C}$ defined the solubility and stability of ferricopiapite. These are the only phase relations determined for coexisting copiapite-group minerals and aqueous solution. Phase relations in this system at $30-40{ }^{\circ} \mathrm{C}$ were estimated by Merwin and Posnjak (1937) on the basis of field observations and extrapolation from the higher temperature conditions. The diagram from Merwin and Posnjak (Fig. 1) indicates that ferricopiapite has a relatively limited range of stability and precipitates

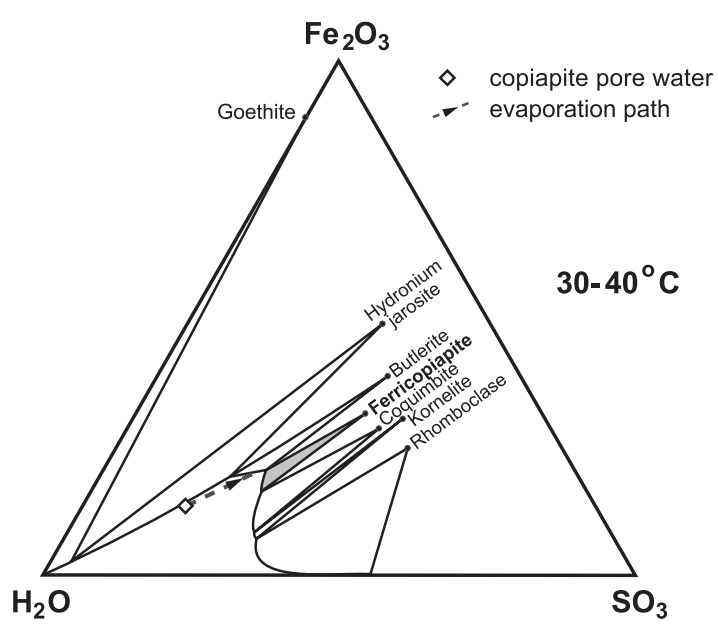

Fig. 1. Solubility relations of minerals in the $\mathrm{Fe}_{2} \mathrm{O}_{3}-\mathrm{SO}_{3}-\mathrm{H}_{2} \mathrm{O}$ system at $30-40{ }^{\circ} \mathrm{C}$ (modified from Merwin and Posnjak, 1937) and the composition of the copiapite pore water from this study, plotted in terms of weight percent. The formulae for kornelite and butlerite are, respectively, $\mathrm{Fe}_{2}\left(\mathrm{SO}_{4}\right)_{3} \cdot 7 \mathrm{H}_{2} \mathrm{O}$ and $\mathrm{Fe}\left(\mathrm{SO}_{4}\right)(\mathrm{OH}) \cdot 2 \mathrm{H}_{2} \mathrm{O}$. 
from very acid, $\mathrm{Fe}^{3+}$-rich and $\mathrm{SO}_{4}$-rich waters. Applying this information to the formation of copiapite-group minerals from acid mine waters has been limited because no previous studies on copiapite have included sampling and analysis of coexisting water.

\section{Methods}

\subsection{Sample collection and preservation}

Copiapite-group mineral samples with coexisting water were collected in July 1998 from the Richmond mine. Restoration of the underground workings in 1988-1990 by the US EPA Superfund Program allowed researchers to enter stopes that had been inactive since the early $1950 \mathrm{~s}$. A series of four drifts branch from the 400-m access tunnel at a five-way intersection. Collapsed and unstable tunnel walls, as well as poor air quality, prevented exploration farther than approximately $20 \mathrm{~m}$ into each of the drifts. In July 1998, during the warm, dry season, water was draining from three of the drifts $(\mathrm{A}, \mathrm{B}$, and $\mathrm{C})$ at rates of 0.003 to $0.006 \mathrm{~m}^{3} \mathrm{~s}^{-1}$, with $\mathrm{pH}$ values averaging 1.0 and temperatures from 37 to $48{ }^{\circ} \mathrm{C}$ (Robinson, 2000). The fourth drift (D) was relatively dry; the water dripping from the ceiling and walls was insufficient to form a flowing stream along the floor. Two 5-L jars (samples 98CR03 and 98CR04) were filled with damp, efflorescent minerals that had formed at this location on loose piles of pyrite remaining from a partial cave-in of massive sulfide material. The dark yellow material formed an apparently monomineralic, wet, unzoned accumulation of $\sim 1 \mathrm{~m}^{2}$ that appeared to have grown in place on the finely granular pyrite.

Pore water was extracted from the copiapite-group mineral samples through centrifugation at $10,000 \mathrm{rpm}$ for $20 \mathrm{~min}$. Approximately $200 \mathrm{~mL}$ of water were obtained and filtered $(0.45-\mu \mathrm{m}$ membrane). The main objective in filtering was to exclude small crystals of copiapite. In more dilute waters, colloidal Fe oxyhydroxides may be present as particles smaller than $0.45 \mu \mathrm{m}$ and result in an overestimation of $\mathrm{Fe}$ and other metals associated with the colloids. However, Fe oxyhydroxides are not stable under the very acid conditions described here. Moreover, the concentration of dissolved $\mathrm{Fe}$ is so high that the presence of colloidal Fe minerals in the water sample would have little influence on the total dissolved Fe concentration. An aliquot of each sample was acidified with $\mathrm{HNO}_{3}$ for cation analysis, and a separate aliquot for $\mathrm{Fe}$ and As speciation was preserved with $\mathrm{HCl}$. Extraction of the pore water was done 3 weeks after collection. The samples had been sealed in the 5-L bottles and stored at temperatures similar to those in D drift. The solid material remaining after centrifugation was stored in four $500-\mathrm{mL}$ containers at $29 \pm 0.02{ }^{\circ} \mathrm{C}$.

An additional copiapite-rich sample (IM-05) that was analyzed for this study was collected from the C drift during 1991. The sample was stored at room temperature in a $10-\mathrm{mL}$ glass vial.

\subsection{Sample description and preparation}

Hydrated Fe-sulfate mineral specimens are known to undergo phase changes in response to changes in humidity and temperature. Waller (1992) provided information on the stability ranges of sulfate minerals in an effort to preserve museum specimens, although copiapite-group minerals were not included in his otherwise comprehensive list (see also Jambor et al., 2000). In this study, care was taken to maintain the copiapite-group mineral samples in a condition similar to that of the field setting. Preparation of the solid samples for analysis was designed to minimize exposure to elevated temperatures and water. For several methods, it was necessary to dry the samples. Any changes that occurred during sample preparation were noted, and the products were analyzed.

The copiapite-group mineral samples that were separated from the pore water by centrifuge were yellow-orange (Munsell color 5Y 5-6/6 Munsell, 1954) and had a thick, dense, tacky consistency. A thin film of opaque brown fluid was present on the surface of the solid material. A few small grains of pyrite $(<2 \mathrm{~mm})$ were disseminated throughout.

For SEM imaging, a portion of sample 98CR04 was removed from the incubator and left to dry at room temperature for $24 \mathrm{~h}$. The sample was examined under a binocular microscope before and after drying. The clumps turned a much lighter yellow color (5Y $7 /$ 8 ) and became less sticky. A dusting of small white crystals $(<1 \mathrm{~mm})$ appeared as sparsely disseminated patches on some copiapite-group mineral surfaces. Separation and XRD analysis of this white material 
from one of the air-dried samples indicated it to be coquimbite. This material was removed from the sample before SEM analysis. The SEM samples were mounted on carbon disks and were coated with gold to prevent charge build-up.

Four subsamples of 98CR04 were prepared for bulk compositional analysis. Two of the subsamples, $\mathrm{A}$ and $\mathrm{C}$, were washed with double-distilled water (DDW), filtered, blotted dry on filter paper, and weighed immediately. Subsample B was washed, filtered, and dried overnight in a desiccator. Subsample D, consisting of material taken directly from the bottle, was blotted on filter paper but without any further preparation.

Samples were prepared for initial powder X-ray diffraction (XRD) by drying in air, grinding with a mortar and pestle, and mounting with petroleum jelly on a glass slide. Samples for more detailed follow-up XRD analysis were removed from their sealed container in the incubator and were side packed into a flat, square aluminum holder, $2.5 \times 2.5 \mathrm{~cm} \times 1 \mathrm{~mm}$. The material was dense and sticky, making it difficult to manipulate. To avoid preferred orientation, great care was taken to avoid massaging the sample surface while packing.

Three polished thin sections of sample 98CR04 were prepared at CANMET in Ottawa for electronprobe microanalysis (EPMA) and proton-induced Xray emission (micro-PIXE) analysis. The sample was placed in a desiccator for 2 days to dry at room temperature. Fragments were mounted in a polyethylene mold $30 \mathrm{~mm}$ in diameter in premixed epoxy (5:1 mixture of CIBA-GEIGY epoxy resin 502 and hardener HY 956) and left overnight to harden. A cold-setting epoxy resin was favored over those of polyester and acrylic because the epoxy resin has strong adhesive properties, a low viscosity, low shrinkage, fairly high polishing hardness, and does not require high heat or pressure for preparation, a feature that was essential because copiapite-group minerals are sensitive to thermal changes. After sample plugs were removed from the molding assemblies, grinding was done using a $15-\mu \mathrm{m}$ diamond-impregnated disc with a petroleum-ether lubricant. The polishing was done on Durener polishing machines using $\mathrm{Pb}$ laps in two successive stages, first with diamond particles of $1-3 \mu \mathrm{m}$ and second with particles of $0-2 \mu \mathrm{m}$. A mixture of mineral oil and kerosene was used as a lubricant. Contact with water was avoided (Stanley and Laflamme, 1998; Laflamme, personal communication, 1999). Lead was found to be below the detection limit of $5 \mathrm{ppm}$ (using micro-PIXE analysis), and thus, contamination from the laps is not a concern for these samples.

\subsection{Analytical methods}

The morphology and texture of the solid samples were examined using a Philips XL30 CP scanning electron microscope (SEM) at the Royal Military College of Canada in Kingston. Spectra from an energy dispersion spectrometer (EDS) were collected using a rastered beam of 10 to $20 \mu \mathrm{m}$ diameter and an accelerating voltage of $10 \mathrm{kV}$.

The ARL-SEMQ electron microprobe at Queen's University was used to perform major-element analyses on the minerals and to confirm their identity. Standard analytical conditions included an accelerating voltage of $15 \mathrm{kV}$, a take-off angle of $52.5^{\circ}$, an emission current of $100 \mathrm{~mA}$, and a beam current of approximately $40 \mathrm{nA}$. Primary analytical standards included synthetic chalcopyrite for $\mathrm{Fe}$, barite for $\mathrm{S}$, kaersutitic amphibole for Na (Smithsonian USNM 143965), and a synthetic glass for $\mathrm{Al}, \mathrm{Mg}, \mathrm{Ca}$, and $\mathrm{Si}$ (US National Bureau of Standards 470). A well-characterized alunite sample from Marysville, UT (Stoffregen and Alpers, 1987), served as a secondary analytical standard for Al and S. A rastered beam and relatively short analysis time (50 s) were chosen to minimize beam damage on the fragile sulfate standards and samples. Analytical spectra were processed by fitting the reference spectra using a least squares program to obtain $k$ ratios, which were corrected using the ZAF program (Goldstein et al., 1992). The secondary alunite standard was analyzed periodically as an unknown, usually every $10-15$ analyses, to ensure consistent results. All primary standards were rechecked at the end of the session. Measured concentrations of $\mathrm{Fe}, \mathrm{Al}$, and $\mathrm{S}$ in the alunite standard and in a pyrite grain were consistently within 1 wt. \% of the published or stoichiometric values, and molar ratios of $\mathrm{Al} / \mathrm{S}$ in alunite and $\mathrm{Fe} / \mathrm{S}$ in pyrite were close to ideal.

The concentrations of trace elements, including $\mathrm{Zn}$, $\mathrm{Cu}$, and $\mathrm{As}$, were determined using micro-PIXE analysis at the Scanning Proton Microprobe Laboratory at the University of Guelph, Ontario. A reduced 
beam current of $1.4 \mathrm{nA}$ was applied to avoid damaging the relatively thin $(10-50 \mu \mathrm{m})$ platy crystals. This required a lengthened analysis time of approximately $700 \mathrm{~s}$. The analysis was terminated when the charge reached $1 \mu \mathrm{C}$. An Al-mylar filter $(250 \mu \mathrm{m}$ thick $)$ in combination with a mylar filter $(125 \mu \mathrm{m}$ thick) was used to stop the backscattered protons and to reduce the intensity and number of X-ray photons with lower energy and longer wavelength. Micro-PIXE analysis is often used as a standardless technique because of the difficulty of finding standards homogeneous with regard to trace elements and because of the success of calculating intensity corrections from an understanding of the physics of the interaction between the proton beam and the sample (Cabri and Campbell, 1998). However, relatively few data on the microanalysis of very hydrous Fe sulfates using either electron or proton beams are available; Fe was therefore analyzed as an unknown by micro-PIXE, and the difference between this value and the one obtained from electron microprobe was used a measure of analytical accuracy. A similar approach had been used successfully on other Fe sulfates, such as voltaite and szomolnokite (Jamieson and Pryzbylowicz, 1997; Jamieson et al., 1999). For the copiapite study, Fe concentrations determined by micro-PIXE on 14 spots averaged 20.15 wt.\% (standard deviation=1.6) compared with 20.23 wt. $\%$ (standard deviation=0.6) measured on 13 spots measured by electron microprobe. Micro-PIXE was used to determine the concentrations of $\mathrm{Ag}, \mathrm{As}, \mathrm{Cd}, \mathrm{Cu}, \mathrm{Fe}, \mathrm{Ga}, \mathrm{Ge}, \mathrm{In}, \mathrm{Mo}$, $\mathrm{Nb}, \mathrm{Ni}, \mathrm{Pb}, \mathrm{Rb}, \mathrm{Sb}, \mathrm{Se}, \mathrm{Sn}, \mathrm{Sr}, \mathrm{Tl}, \mathrm{W}, \mathrm{Y}, \mathrm{Zn}$, and Zr. The results for these elements were evaluated independently in each analysis by ensuring an acceptable fit error and limit of detection (LOD). Concentrations greater than three times the LOD were considered significant. In addition, the spectra for each analysis were examined for residual peaks. According to these criteria, only $\mathrm{Fe}, \mathrm{Zn}, \mathrm{Cu}$, and As were consistently present in significant concentrations. The fit error and LOD were calculated according to the method of Cabri and Campbell (1998).

Initial mineral identification for samples 98CR03 and $98 \mathrm{CR} 04$ was performed by powder XRD using a Siemens powder diffractometer with Ni-filtered $\mathrm{Cu} K \alpha$ radiation $(\lambda=1.5418 \AA)$ at Queen's University. Samples were scanned from 6 to $60^{\circ} 2 \theta$, with a $0.1^{\circ}$ step and a 6-s count time. Sample IM-05 was characterized by powder XRD on a Scintag PAD V diffractometer at the University of California, Davis, using $\mathrm{CuK \alpha}$ radiation $(45 \mathrm{kV}$ and $40 \mathrm{~mA}$ ) with a diffracted beam monochromator and no filter. The samples were scanned from 4 to $71^{\circ} 2 \theta$ with a $0.02^{\circ}$ step and a 2 -s count time. The XRD patterns were then matched by computer with mineral diffraction files (JCPDS, 1997).

Techniques used to determine cell parameters for sample 98CR04 required careful sample preparation and data collection to avoid problems associated with preferred orientation and the presence of multiple species. The sample holder was mounted in a Scintag XI powder diffractometer. Drying the sample to create a powder was not an option, as coquimbite formed soon after removal from the container (Robinson, 2000). The sample was scanned with Ni-filtered $\mathrm{Cu} K \alpha$ radiation from 5 to $100^{\circ} 2 \theta$, with a $0.02^{\circ}$ step and a 10 -s count time. The analysis took $>14 \mathrm{~h}$. Because a minor amount of phase change may have occurred during the sample preparation and analysis, the most critical low-angle refraction data were measured within the first $2 \mathrm{~h}$ of the analysis.

The $\mathrm{pH}$ of pore water samples was measured according to the methods of Nordstrom et al. (2000) using glass-membrane combination electrodes, $\mathrm{H}_{2} \mathrm{SO}_{4}$ solutions for standard buffers, and the Pitzer method for definition of $\mathrm{pH}$ calculated with the PHRQPITZ program (Plummer et al., 1988; Alpers and Nordstrom, 1999).

Chemical constituents in the pore water samples were determined at the USGS laboratories in Boulder, CO. Sulfate concentrations were determined by ion chromatography (Brinton et al., 1996) using a Dionex 2010 i ion chromatograph with $10-\mu \mathrm{L}$ sample loop. Concentrations of major cations (other than the alkalis) and trace metals were measured by inductively coupled plasma-optical emission spectrometry (ICP-OES) using a Leeman Labs DRE. Major cations were analyzed using the radial view, whereas the axial view was used for trace metals. The cations $\mathrm{Na}, \mathrm{K}$, and $\mathrm{Li}$ were analyzed by flame atomic absorption spectrometry (FAAS). Iron redox species were determined using a modification of the FerroZine colorimetric method (Stookey, 1970; To et al., 1999).

Solid copiapite-group mineral samples were prepared for bulk compositional analysis by dissolving 7 to $70 \mathrm{mg}$ subsamples in $50-\mathrm{mL}$ volumetric flasks 
a

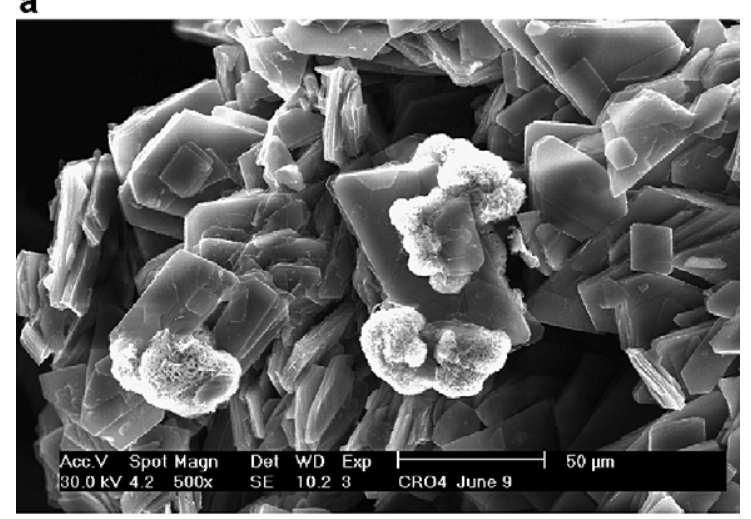

b

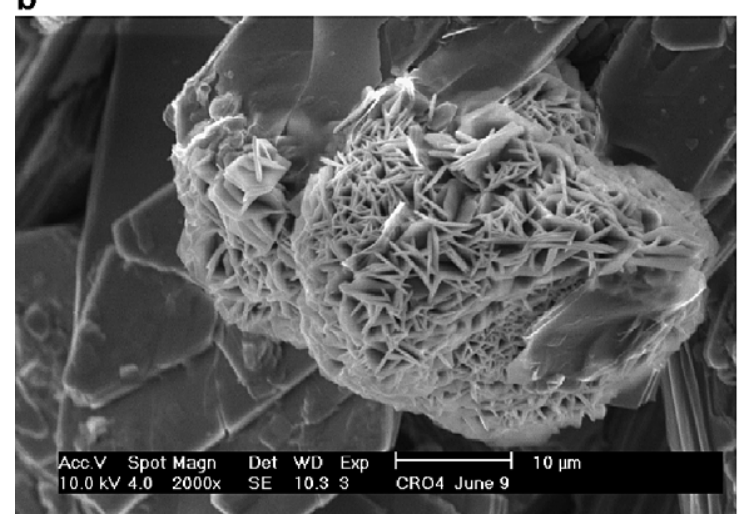

Fig. 2. SEM images of copiapite sample 98CR04 showing two distinct morphologies. The sample consists predominantly of larger platy crystals of magnesiocopiapite, with a minor amount of smaller platy crystals of aluminocopiapite that forms spheroidal aggregates.

containing either DDW, $0.01 \% \mathrm{HCl}(\mathrm{v} / \mathrm{v})$ in DDW, or $1.0 \% \mathrm{HCl}(\mathrm{v} / \mathrm{v})$ in DDW. Impurities were avoided visually when taking aliquots from the finely ground mineral samples. Sample mass was measured using a Sartorius five-place semimicroanalytical balance. All reagents were of purity at least equal to the reagentgrade standards of the American Chemical Society. Double-distilled water and redistilled acids were used in all preparations. Once dissolved, samples were transferred to opaque polyethylene bottles and stored at $4{ }^{\circ} \mathrm{C}$. Four subsamples of $98 \mathrm{CR} 04$ were dissolved separately, as described in the previous section. The resulting solutions were analyzed by the same analytical methods that were used for the pore waters. Sulfate concentrations were determined by IC using the DDW and $0.01 \% \mathrm{HCl}$ splits. Trace metals and major cations were measured using the $0.01 \%$ and
$1.0 \% \mathrm{HCl}$ splits. Reported concentrations for $\mathrm{SO}_{4}$, major cations, and trace metals are the mean of the two splits. Iron redox concentrations were measured using the $1 \% \mathrm{HCl}$ split.

\section{Results}

\subsection{Mineral morphology and paragenesis}

Two distinct morphologies of copiapite-group minerals are visible in the SEM images of sample 98CR04 (Fig. 2a,b). The sample consisted predominantly of larger platy crystals $(10-50 \mu \mathrm{m})$, with a minor amount of smaller platy crystals $(\leq 5 \mu \mathrm{m})$ that formed spheroidal aggregates $\leq 15 \mu \mathrm{m}$ in diameter. Qualitative EDS analyses of both conformed to copiapite-group minerals but with distinct chemical differences. Spectra for the larger platy crystals display strong peaks for $\mathrm{Fe}, \mathrm{Mg}$, and $\mathrm{S}$ with a minor peak for Al (Fig. 3a), whereas the spheroidal aggregates have strong peaks for $\mathrm{Al}, \mathrm{Fe}$, and $\mathrm{S}$ (Fig. $3 \mathrm{~b})$. The predominance and position of the larger platy crystals suggest that these crystals were the original mineral, and the minor spheroidal aggregates of crystals formed later (Fig. 2a,b). It was not possible
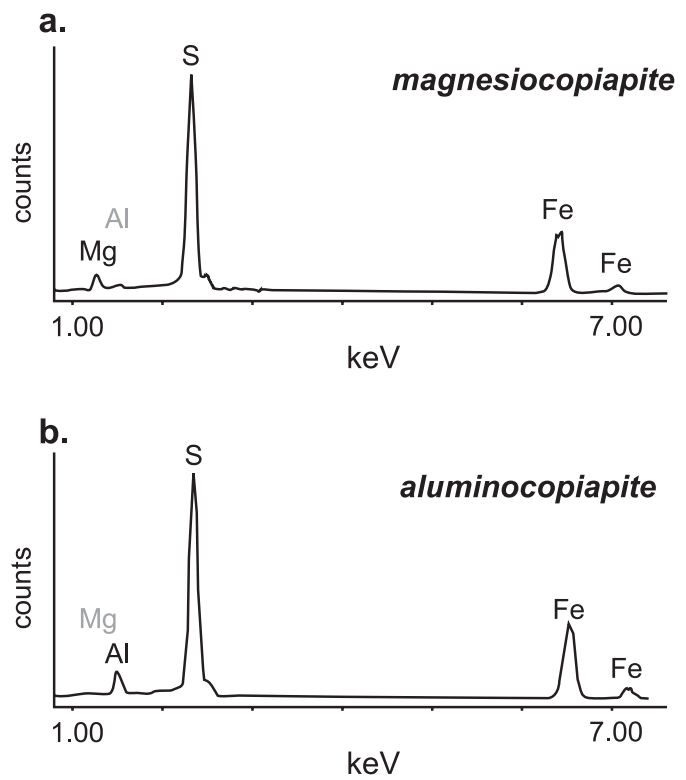

Fig. 3. EDS spectra of (a) major or predominant magnesiocopiapite and (b) minor spheroidal aggregates of aluminocopiapite. 
to analyze these samples by XRD immediately after sampling, but EPMA analysis indicated that the second mineral is aluminocopiapite rather than the coquimbite that sometimes formed on air drying.

Following the nomenclature of Jambor (1994), primary minerals are considered to be those formed prior to weathering, and secondary minerals are those formed during the weathering of deposited materials, such as tailings or waste rocks, but prior to additional human influence. Tertiary minerals are those formed after human disturbance, such as during drying after removal from the depositional site, and quaternary minerals are those that form long after sample collection, i.e., by transformation during storage, such as those that occur on some museum specimens of pyrite and marcasite (Jambor, 1994). Our interpretation of the copiapite-group minerals from Iron Mountain is that the magnesiocopiapite is secondary, having formed after mining but before sample collection. The aluminocopiapite is probably tertiary because it likely crystallized from the associated liquid after removal of the sample (liquid and solid) from its original setting; however, a quaternary origin as an artifact of sample preparation or storage cannot be discounted.

\subsection{Bulk mineral composition}

Composition data from wet-chemical analysis of four subsamples of the solid fraction of sample 98CR04 and of sample IM-05 are reported in Table 3 , which also gives the theoretical compositions of the five end-member species of the copiapite-group minerals closest to the measured compositions (formulae shown in Table 2). Within this mineral group, small changes in wt.\% values of $\mathrm{Mg}, \mathrm{Al}$, and other $A$ site cations can result in large changes in the relative amounts of end-member components because, in all members, the content of $\mathrm{Fe}, \mathrm{S}$, and $\mathrm{O}$ is $>94 \%$ on a mass basis.

The measured bulk compositions of subsamples 98CR04-A, -B, -C, and -D (Table 3) correspond to

Table 3

Ideal compositions of four members of the copiapite group and measured bulk compositions of four subsamples of sample $98 \mathrm{CR} 04$ and of sample IM-05 from the Richmond mine

\begin{tabular}{|c|c|c|c|c|c|c|c|c|c|c|c|c|c|}
\hline & $\begin{array}{l}\text { Magnesio- } \\
\text { copiapite }\end{array}$ & $\begin{array}{l}\text { Alumino- } \\
\text { copiapite }\end{array}$ & Copiapite & $\begin{array}{l}\text { Zinco- } \\
\text { copiapite }\end{array}$ & $\begin{array}{l}\text { Ferri- } \\
\text { copiapite }\end{array}$ & A & $\begin{array}{c}\text { A- } \\
\text { corrected }\end{array}$ & B & $\begin{array}{c}\text { B- } \\
\text { corrected }\end{array}$ & $\mathrm{C}$ & $\begin{array}{c}\mathrm{C}- \\
\text { corrected }\end{array}$ & D & IM-05 \\
\hline $\mathrm{Mg}$ & 1.99 & & & & & 1.45 & 1.615 & 1.62 & 1.607 & 1.31 & 1.630 & 0.98 & 0.14 \\
\hline $\mathrm{Fe}_{\text {total }}$ & 18.33 & 18.43 & 22.34 & 17.74 & 21.17 & 16.6 & 18.487 & 18.3 & 18.149 & 15.0 & 18.667 & 14.7 & 19.9 \\
\hline $\mathrm{Fe}^{2+}$ & 0 & 0 & 4.47 & 0 & 0 & 0.57 & 0.635 & 0.87 & 0.863 & 0.66 & 0.821 & 0.77 & 2.4 \\
\hline $\mathrm{Fe}^{3+}$ & 18.33 & 18.43 & 17.87 & 17.74 & 21.17 & 16.0 & 17.818 & 17.4 & 17.257 & 14.4 & 17.796 & 13.9 & 17.5 \\
\hline $\mathrm{Al}$ & & 1.48 & & & & 0.078 & 0.087 & 0.10 & 0.099 & 0.085 & 0.106 & 0.37 & $<0.02$ \\
\hline S & 15.79 & 15.87 & 15.39 & 15.28 & 15.62 & 13.7 & 15.290 & 15.2 & 15.075 & 12.2 & 15.183 & 13.0 & 15.4 \\
\hline $\mathrm{Zn}$ & & & & 5.19 & & 0.11 & 0.123 & 0.12 & 0.199 & 0.10 & 0.124 & 0.56 & 2.0 \\
\hline $\mathrm{Cu}$ & & & & & & 0.0031 & 0.003 & 0.0024 & 0.002 & 0.0021 & 0.003 & 0.025 & 0.0098 \\
\hline $\mathrm{Ca}$ & & & & & & 0.41 & 0.457 & 0.97 & 0.962 & 0.26 & 0.324 & 0.17 & 0.16 \\
\hline $\mathrm{Si}$ & & & & & & 0.015 & 0.016 & 0.028 & 0.028 & 0.022 & 0.027 & 0.0067 & $<0.002$ \\
\hline $\mathrm{Na}$ & & & & & & 0.014 & 0.016 & 0.030 & 0.029 & 0.014 & 0.017 & 0.024 & 0.12 \\
\hline K & & & & & & 0.008 & 0.009 & 0.03 & 0.029 & 0.016 & 0.019 & 0.0056 & 0.02 \\
\hline $\mathrm{Pb}$ & & & & & & $<0.001$ & & 0.002 & 0.002 & $<0.001$ & & $<0.001$ & $<0.001$ \\
\hline As & & & & & & $<0.006$ & & 0.008 & 0.008 & 0.006 & 0.007 & $<0.006$ & $<0.006$ \\
\hline B & & & & & & 0.004 & 0.005 & 0.002 & 0.002 & 0.0022 & 0.003 & 0.0015 & 0.006 \\
\hline Co & & & & & & 0.004 & 0.005 & 0.003 & 0.003 & 0.0026 & 0.003 & 0.0024 & 0.0009 \\
\hline $\mathrm{Mn}$ & & & & & & 0.0069 & 0.008 & 0.0051 & 0.005 & 0.0051 & 0.006 & 0.0059 & \\
\hline$\Sigma$ & 36.1 & 35.8 & 37.7 & 38.2 & 36.8 & 32.4 & 36.12 & 36.4 & 36.12 & 29.0 & 36.12 & 37.8 & \\
\hline$\Sigma(\mathrm{O}, \mathrm{H})$ & 63.9 & 64.2 & 62.3 & 61.8 & 63.2 & 67.7 & 63.9 & 63.6 & 63.9 & 71.0 & 63.9 & 62.2 & \\
\hline Total & & & & & & & 100.00 & & 100.0 & & 100.00 & & \\
\hline
\end{tabular}

Subsamples A and C were washed, filtered, and weighed immediately, whereas subsample B was washed, filtered, and allowed to dry overnight. Subsample D represents unwashed material taken directly from the sample container. Hydrogen and oxygen content of subsamples assumed to be equal to concentrations in magnesiocopiapite. All concentration values in wt.\%.

Corrected compositions of subsamples A, B, and C with water content equivalent to that of magnesiocopiapite. 
Table 4

Microanalyses (wt.\%) of copiapite-group minerals in sample 98CR04 from the Richmond mine

\begin{tabular}{|c|c|c|c|c|c|c|c|c|c|c|c|c|c|c|c|c|}
\hline No. & 3 & 13 & 5 & 1 & 2 & 14 & 4 & 11 & 6 & 8 & 12 & 7 & 10 & Average & S.D. & $\begin{array}{l}\text { Magnesio- } \\
\text { copiapite }\end{array}$ \\
\hline \multicolumn{17}{|c|}{ Partly dehydrated } \\
\hline $\mathrm{Mg}$ & 2.06 & 2.06 & 2.05 & 2.01 & 1.92 & 1.91 & 1.46 & 0.82 & 0.67 & 0.4 & 0.37 & 0.35 & 0.34 & 1.26 & 0.77 & 2.19 \\
\hline $\mathrm{Al}$ & 0.24 & 0.2 & 0.17 & 0.28 & 0.28 & 0.2 & 0.34 & 0.93 & 1.06 & 1.36 & 1.1 & 1.49 & 1.45 & 0.7 & 0.535 & \\
\hline $\mathrm{S}$ & 18.71 & 18.42 & 17.3 & 17.34 & 17.92 & 18.61 & 17.78 & 17.94 & 17.59 & 17.67 & 17.47 & 17.97 & 17.69 & 17.88 & 0.456 & 17.32 \\
\hline $\mathrm{Na}$ & 0.08 & 0 & 0 & 0.11 & 0 & 0 & 0 & 0 & 0 & 0 & 0 & 0 & 0.09 & 0.02 & 0.041 & \\
\hline $\mathrm{K}$ & 0 & 0 & 0 & 0 & 0.05 & 0 & 0.12 & 0 & 0 & 0.14 & 0.14 & 0 & 0 & 0.03 & 0.058 & \\
\hline $\mathrm{Cu}$ & 0.027 & 0.027 & 0.027 & 0.027 & 0.027 & 0.027 & 0.027 & 0.027 & 0.027 & 0.027 & 0.027 & 0.027 & 0.027 & 0.027 & 0.011 & \\
\hline $\mathrm{Zn}$ & 0.144 & 0.144 & 0.144 & 0.144 & 0.144 & 0.144 & 0.144 & 0.144 & 0.144 & 0.144 & 0.144 & 0.144 & 0.144 & 0.144 & 0.023 & \\
\hline As & 0.0064 & 0.0064 & 0.0064 & 0.0064 & 0.0064 & 0.0064 & 0.0064 & 0.0064 & 0.0064 & 0.0064 & 0.0064 & 0.0064 & 0.0064 & 0.0064 & 0.004 & \\
\hline$\Sigma$ & 42.89 & 41.91 & 39.68 & 40.28 & 40.42 & 41.15 & 40.64 & 39.86 & 39.61 & 39.64 & 38.70 & 39.59 & 39.88 & 40.32 & & 39.63 \\
\hline$\Sigma(\mathrm{O}, \mathrm{H})$ & 57.11 & 58.09 & 60.32 & 59.72 & 59.58 & 58.85 & 59.36 & 60.14 & 60.39 & 60.36 & 61.30 & 60.41 & 60.12 & 59.68 & & 60.37 \\
\hline \multicolumn{17}{|c|}{ After correction for water content $*$} \\
\hline $\mathrm{Mg}$ & 1.85 & 1.85 & 1.84 & 1.80 & 1.72 & 1.71 & 1.31 & 0.73 & 0.60 & 0.36 & 0.33 & 0.31 & 0.30 & 1.13 & & \\
\hline $\mathrm{Fe}_{\text {Total }}$ & 19.28 & 18.87 & 17.91 & 18.16 & 17.99 & 18.15 & 18.61 & 17.92 & 18.02 & 17.83 & 17.43 & 17.57 & 18.04 & 18.14 & & \\
\hline $\mathrm{S}$ & 16.77 & 16.51 & 15.5 & 15.5 & 16.06 & 16.68 & 15.94 & 16.08 & 15.77 & 15.84 & 15.66 & 16.11 & 15.86 & 16.03 & & \\
\hline $\mathrm{Na}$ & 0.07 & 0 & 0 & 0.10 & 0 & 0 & 0 & 0 & 0 & 0 & 0 & 0 & 0.08 & 0.02 & & \\
\hline $\mathrm{K}$ & 0 & 0 & 0 & 0 & 0.04 & 0 & 0.11 & 0 & 0 & 0.12 & 0.13 & 0 & 0 & 0.03 & & \\
\hline $\mathrm{Ca}$ & 0.11 & 0 & 0 & 0.09 & 0 & 0 & 0 & 0 & 0 & 0 & 0 & 0 & 0 & 0.01 & & \\
\hline $\mathrm{Cu}$ & 0.024 & 0.024 & 0.024 & 0.024 & 0.024 & 0.024 & 0.024 & 0.024 & 0.024 & 0.024 & 0.024 & 0.024 & 0.024 & 0.024 & & \\
\hline $\mathrm{Zn}$ & 0.129 & 0.129 & 0.129 & 0.129 & 0.129 & 0.129 & 0.129 & 0.129 & 0.129 & 0.129 & 0.129 & 0.129 & 0.129 & 0.129 & & \\
\hline As & 0.006 & 0.006 & 0.006 & 0.006 & 0.006 & 0.006 & 0.006 & 0.006 & 0.006 & 0.006 & 0.006 & 0.006 & 0.006 & 0.006 & & \\
\hline Totals & 38.45 & 37.57 & 35.57 & 36.11 & 36.23 & 36.89 & 36.43 & 35.73 & 35.51 & 35.53 & 34.69 & 35.49 & 35.75 & 36.15 & & \\
\hline
\end{tabular}

All elements were determined by EPMA except that of $\mathrm{Cu}, \mathrm{Zn}$, and As which were analyzed by micro-PIXE. Concentrations of $\mathrm{Cu}$, $\mathrm{Zn}$, and As are the average of 14 analyses shown in Table 5, and the standard deviations refer to these data. Composition of partly dehydrated magnesiocopiapite is that of the ideal formula with $14 \mathrm{H}_{2} \mathrm{O}$.

* After correction for water content, values listed are those obtained by lowering the concentrations of all constituents so that the water content is similar to that of ideal magnesiocopiapite. See Table 3 for ideal compositions of magnesiocopiapite and aluminocopiapite. 
magnesiocopiapite with minor amounts of $\mathrm{Al}, \mathrm{Zn}$, and $\mathrm{Fe}^{2+}$. The data are consistent with the SEM results indicating that the predominant mineral is $\mathrm{Mg}$ rich, and the less abundant one is $\mathrm{Al}$ rich. The composition of subsample B corresponds most closely to the composition of end-member magnesiocopiapite; subsamples $\mathrm{A}$ and $\mathrm{C}$ contained excess water. The small amount of $\mathrm{Ca}$ measured is probably due to gypsum included with the bulk sample. The data for subsamples 98CR04-A and -C were corrected to account for the excess water by increasing the concentrations of the non- $\mathrm{H}_{2} \mathrm{O}$ components by an amount necessary to bring the apparent $\mathrm{H}_{2} \mathrm{O}$ equal to the ideal composition of magnesiocopiapite (Table 3). The composition of sample IM-05 corresponds to copiapite sensu stricto, with a significant amount of $\mathrm{Zn}$ substitution for $\mathrm{Fe}^{2+}$.

\subsection{Mineral microanalysis}

In polished thin section, copiapite is opaque in transmitted light and pale brownish gray with yellow internal reflections in reflected light. Grains are euhedral to rectangular in shape and are $\leq 50 \mu \mathrm{m}$ in length. The two copiapite-group minerals that were clearly distinguished in the SEM images could not be discerned petrographically, probably because of the small size and similar optical properties.

Measured compositions of copiapite-group minerals from microanalysis of sample 98CR04 are reported in Table 4. The $\mathrm{Fe}$ and $\mathrm{S}$ concentrations are somewhat higher than values of end members of the copiapite group (Table 3), but the ratio of $\mathrm{Fe}$ to $\mathrm{S}$ is consistent with the stoichiometric ratio. Copiapitegroup minerals are especially hydrous, and it is probable that they suffer structural water loss due to the heat from the beam current during EPMA (Goldstein et al., 1992). Apparently, this may occur without significant damage to the framework of the mineral (Posnjak and Merwin, 1922; Fanfani et al., 1973). Concentrations of $\mathrm{Fe}$ and $\mathrm{S}$ in the average electron microprobe analysis (Table 4) correspond approximately to the hypothetical composition of a partially dehydrated magnesiocopiapite which has lost six of 20 waters of hydration (i.e., $n=14$ ). Six molecules of water per formula unit is the number that is considered to be interstitial and not bonded to interstitial cations. The apparent water concentrations shown in Table 4 are computed by difference based on the EPMA data. The EPMA data in Table 4 were corrected for loss of $\mathrm{H}_{2} \mathrm{O}$ by lowering apparent concentrations by the amount needed to achieve corrected water contents close to the ideal formulae for copiapite-group minerals (Table 4). Prior to correction, the average non- $\mathrm{H}_{2} \mathrm{O}$ total was $40.32 \mathrm{wt} . \%$, corresponding to an apparent water content of 59.68 wt.\%. After correction, the average non- $\mathrm{H}_{2} \mathrm{O}$ total is $36.15 \mathrm{wt} . \%$, and the apparent water content is $63.85 \mathrm{wt} . \%$, which is close to the ideal composition of magnesiocopiapite (36.12 and $63.88 \mathrm{wt} . \%$, respectively).

The micro-PIXE analyses were determined on the same polished sections as those used for EPMA but not on the same spots (because of beam damage). Therefore, the concentrations of $\mathrm{Zn}, \mathrm{Cu}$, and As listed in Table 4 are the average values from Table 5. The concentration of Fe was determined by both EPMA and micro-PIXE. The results listed in Tables 4 and 5 closely agree in $\mathrm{Fe}$ concentrations, indicating that the dehydration effect of the proton beam was similar to that of the electron beam.

A rastered electron beam approximately $20 \mu \mathrm{m}$ in diameter was used during EPMA to minimize beam damage to the samples. The range in $\mathrm{Mg}$ and $\mathrm{Al}$ concentrations may therefore be greater than indi-

Table 5

$\mathrm{Fe}, \mathrm{Zn}, \mathrm{Cu}$, and As concentrations (in ppm) in copiapite-group minerals (predominantly magnesiocopiapite) as determined by micro-PIXE

\begin{tabular}{lllllllrl}
\hline & Fe & LOD & Zn & LOD & Cu & LOD & As & LOD \\
\hline PX1 & 198,480 & 223 & 1410 & 8 & 200 & 6 & 40 & 7 \\
PX2 & 189,280 & 157 & 1290 & 8 & 550 & 4 & 190 & 3 \\
PX3 & 192,510 & 120 & 1260 & 3 & 230 & 5 & 50 & 6 \\
PX4 & 193,800 & 241 & 1260 & 5 & 290 & 5 & 50 & 7 \\
PX5 & 196,090 & 221 & 1220 & 8 & 410 & 4 & 110 & 4 \\
PX6 & 221,450 & 297 & 1550 & 5 & 280 & 5 & 60 & 5 \\
PX7 & 230,070 & 380 & 1730 & 8 & 320 & 5 & 60 & 6 \\
PX8 & 203,290 & 236 & 1870 & 4 & 220 & 6 & 60 & 6 \\
PX9 & 164,270 & 169 & 980 & 6 & 150 & 7 & 40 & 7 \\
PX10 & 205,980 & 201 & 1650 & 8 & 130 & 7 & 40 & 7 \\
PX11 & 203,600 & 207 & 1530 & 2 & 250 & 5 & 50 & 6 \\
PX12 & 221,320 & 90 & 1520 & 7 & 230 & 5 & 40 & 7 \\
PX13 & 206,480 & 170 & 1440 & 3 & 310 & 5 & 60 & 6 \\
PX14 & 194,700 & 253 & 1380 & 7 & 220 & 5 & 40 & 7 \\
Average & 201,520 & & 1440 & & 270 & & 60 & \\
S.D. & 16,220 & & 228 & & 108 & & 40 & \\
\hline
\end{tabular}

Eighteen other trace elements were analyzed and not detected at levels greater than three times the LOD (see text). LOD-limit of detection; S.D.- - standard deviation. 
cated by the bulk compositions because the analytical volume sampled by the electron beam may include various proportions of magnesiocopiapite and aluminocopiapite. The covariation of $\mathrm{Mg}$ and $\mathrm{Al}$ is also systematic in that the Mg-rich analyses have generally lower $\mathrm{Al}$, and the Al-rich grains have lower $\mathrm{Mg}$ (Table 4).

Mineral formulae corresponding to the EPMA analyses (Table 6) were calculated assuming that $\mathrm{Fe}^{2+} / \mathrm{Fe}^{3+}$ was equal to the average $\mathrm{Fe}^{2+} / \mathrm{Fe}^{3+}$ measured for the bulk analyses because this ratio cannot be measured directly by EPMA. The average values of $\mathrm{Cu}, \mathrm{Zn}$, and $\mathrm{As}$ concentrations from the micro-PIXE data were used. Preliminary analysis of the data indicated that determinations of sulfur as sulfate were very close to the ideal stoichiometry. Therefore, sulfate was assumed to be present as six moles per formula unit modified by $0.001 \mathrm{~mol}$ of arsenate based on the average micro-PIXE data. Arsenic was assumed to substitute for $\mathrm{SO}_{4}^{2-}$ as $\mathrm{AsO}_{4}^{3-}$, as has been suggested for other sulfate minerals such as jarosite (Dutrizac et al., 1987; Savage et al., this volume). The remaining +14 charges in the general formula for copiapite-group minerals were distributed among the other cations. These calculations also assume $2 \mathrm{OH}$ for $6 \mathrm{~S}$ per formula unit and thus do not test the alternative crystal chemical model of Hawthorne et al. (2000).

Calculation of the formulae corresponding to the bulk compositional data (also shown in Table 6) was

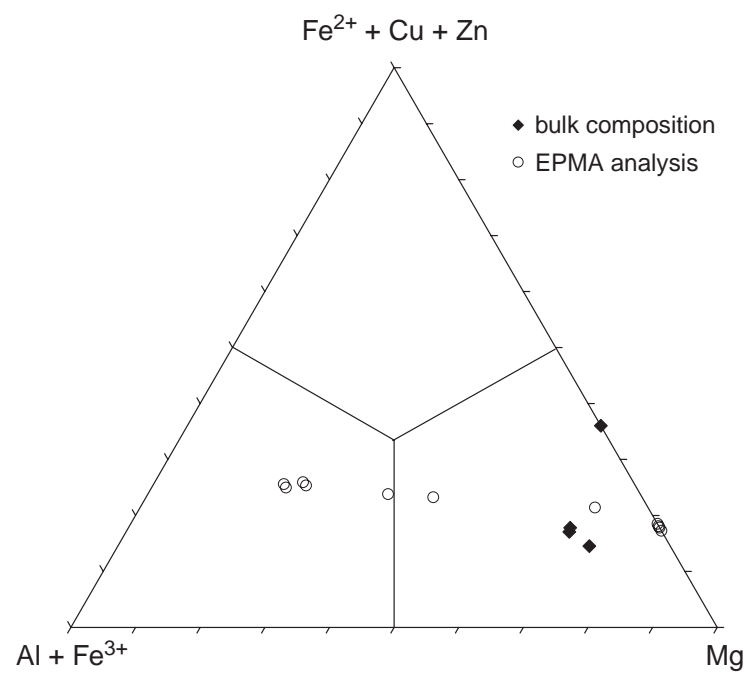

Fig. 4. Copiapite compositions analyzed (this study) plotted in terms of the relative proportion of $A$ site cations. The triangle is divided into three fields corresponding to magnesiocopiapite, aluminocopiapite, and copiapite sensu stricto. The trace amounts of $\mathrm{Cu}$ and $\mathrm{Zn}$ were included with the $\mathrm{Fe}^{2+}$ end member. Most of the analyses fall in the field of magnesiocopiapite, including the bulk compositions. Others are aluminocopiapite or a mixture of magnesiocopiapite and aluminocopiapite.

more direct because, for these analyses, $\mathrm{Fe}^{2+}$ and $\mathrm{Fe}_{\text {total }}$ were determined analytically, and $\mathrm{Fe}^{3+}$ was computed by difference (Table 3 ). The structural formulae in Table 6 were used to calculate the relative proportions of three end-member components of the mineral group, as shown in Fig. 4. It was assumed that the $R$ site was

Table 6

Structural formulae for copiapite-group mineral analyses shown in Tables 3 and 4

\begin{tabular}{lllllllllllllllllll}
\hline No. & 5 & 13 & 1 & 2 & 3 & 14 & 4 & 11 & 6 & 8 & 12 & 7 & 10 & $\mathrm{~A}$ & $\mathrm{~B}$ & $\mathrm{C}$ & $\mathrm{D}$ \\
\hline $\mathrm{Al}$ & 0.070 & 0.080 & 0.113 & 0.117 & 0.092 & 0.083 & 0.140 & 0.391 & 0.443 & 0.550 & 0.479 & 0.624 & 0.595 & 0.042 & 0.049 & 0.051 & 0.205 \\
$\mathrm{Fe}^{3+}$ & 3.836 & 3.853 & 3.787 & 3.820 & 3.828 & 3.868 & 3.938 & 3.887 & 3.884 & 3.848 & 3.920 & 3.802 & 3.823 & 4.105 & 4.130 & 4.130 & 3.726 \\
$\mathrm{Fe}^{2+}$ & 0.168 & 0.169 & 0.166 & 0.167 & 0.168 & 0.170 & 0.173 & 0.170 & 0.170 & 0.169 & 0.172 & 0.167 & 0.168 & 0.146 & 0.206 & 0.189 & 0.206 \\
$\mathrm{Mg}$ & 0.944 & 0.904 & 0.902 & 0.890 & 0.879 & 0.875 & 0.664 & 0.382 & 0.311 & 0.185 & 0.179 & 0.163 & 0.155 & 0.855 & 0.884 & 0.864 & 0.604 \\
$\mathrm{Ca}$ & 0.000 & 0.000 & 0.027 & 0.000 & 0.028 & 0.000 & 0.000 & 0.000 & 0.000 & 0.000 & 0.000 & 0.000 & 0.000 & 0.000 & 0.000 & 0.000 & 0.000 \\
$\mathrm{Na}$ & 0.000 & 0.000 & 0.053 & 0.000 & 0.036 & 0.000 & 0.000 & 0.000 & 0.000 & 0.000 & 0.000 & 0.000 & 0.044 & 0.009 & 0.017 & 0.010 & 0.016 \\
$\mathrm{~K}$ & 0.000 & 0.000 & 0.000 & 0.015 & 0.000 & 0.000 & 0.034 & 0.000 & 0.000 & 0.040 & 0.042 & 0.000 & 0.000 & 0.000 & 0.009 & 0.006 & 0.000 \\
$\mathrm{Cu}$ & 0.005 & 0.004 & 0.005 & 0.005 & 0.004 & 0.004 & 0.005 & 0.005 & 0.005 & 0.005 & 0.005 & 0.005 & 0.005 & 0.000 & 0.000 & 0.001 & 0.006 \\
$\mathrm{Zn}$ & 0.024 & 0.023 & 0.024 & 0.024 & 0.022 & 0.024 & 0.024 & 0.025 & 0.024 & 0.024 & 0.025 & 0.024 & 0.024 & 0.024 & 0.024 & 0.025 & 0.128 \\
$\mathrm{As}$ & 0.001 & 0.001 & 0.001 & 0.001 & 0.001 & 0.001 & 0.001 & 0.001 & 0.001 & 0.001 & 0.001 & 0.001 & 0.001 & 0.000 & 0.001 & 0.001 & 0.000 \\
$\mathrm{~S}$ & 5.999 & 5.999 & 5.999 & 5.999 & 5.999 & 5.999 & 5.999 & 5.999 & 5.999 & 5.999 & 5.999 & 5.999 & 5.999 & 6.000 & 6.000 & 6.000 & 6.000 \\
$\mathrm{R}$ & 3.906 & 3.933 & 3.900 & 3.937 & 3.920 & 3.951 & 4.000 & 4.000 & 4.000 & 4.000 & 4.000 & 4.000 & 4.000 & 4.000 & 4.000 & 4.000 & 3.981 \\
$\mathrm{~A}$ & 1.141 & 1.100 & 1.177 & 1.086 & 1.137 & 1.073 & 0.944 & 0.860 & 0.837 & 0.781 & 0.780 & 0.785 & 0.814 & 1.181 & 1.310 & 1.270 & 0.960 \\
\hline
\end{tabular}

$\mathrm{Fe}^{2+}$ and $\mathrm{Fe}^{3+}$ were measured directly for samples $\mathrm{A}, \mathrm{B}, \mathrm{C}$, and $\mathrm{D}$, and this ratio applied to the other analyses. $R$ refers to the sum of cations on the $R$ site, limited to a maximum of 4.000 , as discussed in the text. $A$ refers to the number of cations on the $A$ site, including $\mathrm{Mg}, \mathrm{Fe}^{2+}, \mathrm{Cu}, \mathrm{Zn}$, $\mathrm{Ca}, \mathrm{K}, \mathrm{Na}$, and any excess $\mathrm{Al}$ and $\mathrm{Fe}^{3+}$. 
filled with $\mathrm{Fe}^{3+}$ and $\mathrm{Al}^{3+}$ to a maximum of 4.0 cations (relative to $6 \mathrm{~S}$ atoms), and excess trivalent cations were assigned to the $A$ site. This results in several formulae in which $A$ contains $>1.0$ cations, but the excesses are small in view of the uncertainty associated with $\mathrm{Fe}^{2+} / \mathrm{Fe}^{3+}$. Fig. 4 confirms that seven of the 13 EPMA analyses are magnesiocopiapite whose compositions are similar to those of the measured bulk compositions. The average of five EPMA analyses closest to the $\mathrm{Mg}$ end member correspond to $\left(\mathrm{Mg}_{0.90} \mathrm{Fe}_{0.17}^{2+} \mathrm{Zn}_{0.02} \mathrm{Cu}_{0.01}\right)_{\sum 1.10}\left(\mathrm{Fe}_{3.83}^{3+} \mathrm{Al}_{0.09}\right)_{\sum 3.92}$ $\left(\mathrm{SO}_{4}\right)_{6.00}(\mathrm{OH})_{1.96} \cdot 20 \mathrm{H}_{2} \mathrm{O}$. Four of the remaining six analyses correspond to aluminocopiapite, and two are intermediate compositions, possibly reflecting mixtures of magnesiocopiapite and aluminocopiapite.

Small changes in overall cation proportions can result in large changes in the relative proportions of cations on the $A$ site, thereby affecting the position of the samples, as plotted in Fig. 4. For example, although it has been assumed that the average $\mathrm{Cu}$ and $\mathrm{Zn}$ concentrations as measured by micro-PIXE are present in each of the copiapite-group minerals analyzed, it is possible that these trace elements vary with the major elements in the structure. It was not possible to determine this because $\mathrm{Cu}$ and $\mathrm{Zn}$ were not measured on the same spots as the other elements. If $\mathrm{Cu}$ and $\mathrm{Zn}$ are present at lower concentrations than the average values, the position of the points in Fig. 4 would move slightly toward the Mg apex.

To illustrate uncertainties in the computed mineral formulae, the assumptions with regard to $\mathrm{Cu}$ and $\mathrm{Zn}$ content and $\mathrm{Fe}^{2+} / \mathrm{Fe}^{3+}$ ratio can be tested for the most $\mathrm{Mg}$ rich analysis in Table 6 (analysis 5). If it is assumed that there is no $\mathrm{Cu}$ or $\mathrm{Zn}$ in analysis 5 , the cations present on the $A$ site would change from $\mathrm{Mg}_{0.827}\left(\mathrm{Fe}^{2+}\right.$, $\mathrm{Cu}, \mathrm{Zn})_{0.173}\left(\mathrm{Al}, \mathrm{Fe}^{3+}\right)_{0}$ to $\mathrm{Mg}_{0.849} \mathrm{Fe}_{0.151}^{2+}\left(\mathrm{Al}, \mathrm{Fe}^{3+}\right)_{0}$. There is also some uncertainty associated with applying to all of the EPMA analyses the average $\mathrm{Fe}^{2+} / \mathrm{Fe}^{3+}$ value obtained from the bulk. However, the relatively close fit between the calculated and the expected occupancy of the $A$ and $R$ sites indicates that this value of $\mathrm{Fe}^{2+} / \mathrm{Fe}^{3+}$ is reasonable.

\subsection{Crystallographic data}

Powder XRD reveals two distinct copiapite-group minerals (Fig. 5). Unit-cell parameters for the more abundant mineral were determined by least squares

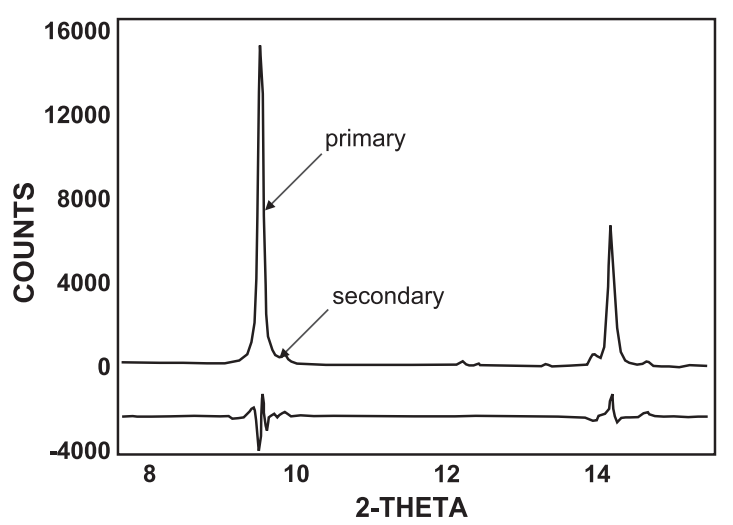

Fig. 5. Part of the diffraction pattern for CR04 showing the characteristic peaks for two copiapite-group minerals, magnesiocopiapite with strong peaks at 9.5 and $14.3^{\circ} 2 \theta$, and a second copiapite-group mineral with weaker peaks at 9.8 and 14.7. The solid line indicates the Rietveld fit for this part of the pattern. The lower solid line represents the observed counts minus the calculated counts for the magnesiocopiapite.

refinement using the computer programs WinFit (Krumm, 1997) and Celsiz (Hay, 1995). Problems of preferred orientation and the presence of mixtures complicated the diffraction pattern, making it impossible to complete a successful Rietveld analysis. The most abundant mineral present in the diffraction pattern was determined to have $a=7.350(5)$, $b=18.803(10), c=7.395(5) \AA, \alpha=91.4(5), \beta=102.2(5)$, $\gamma=98.9(5)^{\circ}, V=985.5 \AA^{3}$. These results are consistent with data for magnesiocopiapite (Bayliss and Atencio, 1985). A small secondary XRD peak is also present with a (020) peak position at $9.85^{\circ} 2 \theta$, corresponding to an estimated value for the $b$-axis of $17.94 \AA$. This secondary (020) peak cannot correspond to aluminocopiapite as the cell dimensions for magnesiocopiapite and aluminocopiapite are very similar and would not produce separate peaks. Although it was not possible to refine the cell parameters for the second mineral because only the $(0 k 0)$ reflections were obtained from the small amount of material present, the $b$ parameter is significantly smaller than that of the accompanying magnesiocopiapite and is similar to that of the examples of ferricopiapite listed by Bayliss and Atencio (1985).

\subsection{Pore water composition}

The composition of pore water extracted from the copiapite-group mineral samples is listed in Table 7. 
Table 7

Composition of copiapite pore water samples $\left(\mathrm{mg} \mathrm{L}^{-1}\right)$ extracted from copiapite-group mineral samples 98CR03 and 98CR04, Richmond mine

\begin{tabular}{|c|c|c|c|}
\hline & \multirow{2}{*}{$\frac{\text { WA-98CR03 }}{\text { FA }}$} & \multirow{2}{*}{$\frac{\text { WA-98CR03 }}{\text { FU }}$} & \multirow{2}{*}{$\begin{array}{l}\text { WA-98CR04 } \\
\text { FA }\end{array}$} \\
\hline & & & \\
\hline Temperature $\left[{ }^{\circ} \mathrm{C}\right]$ & 30 & 30 & 30 \\
\hline $\mathrm{pH}$ & $-0.9 \pm 0.2$ & $-0.9 \pm 0.2$ & $-0.9 \pm 0.2$ \\
\hline $\mathrm{Eh}(\mathrm{mV})$ & 800 & 800 & 800 \\
\hline $\mathrm{Fe}_{\text {Total }}$ & 162000 & 160000 & 160000 \\
\hline $\mathrm{Fe}^{3+}$ & 148000 & 147000 & 148000 \\
\hline $\mathrm{Fe}^{2+}$ & 13600 & 13200 & 11700 \\
\hline $\mathrm{Fe}^{2+} / \mathrm{Fe}^{3+}$ & 0.091 & 0.090 & 0.079 \\
\hline $\mathrm{Al}$ & 6580 & 6380 & 11100 \\
\hline $\mathrm{Mg}$ & 3620 & 3630 & 2940 \\
\hline $\mathrm{Zn}$ & 1720 & 1660 & 1830 \\
\hline $\mathrm{Cu}$ & 669 & 681 & 789 \\
\hline $\mathrm{As}_{\text {Total }}$ & 152 & 151 & 157 \\
\hline $\mathrm{As}^{3+}$ & 3.32 & 3.34 & 3.00 \\
\hline $\mathrm{Ca}$ & 107 & 110 & 106 \\
\hline $\mathrm{Na}$ & 79.6 & 74.2 & 70.2 \\
\hline $\mathrm{Mn}$ & 73.8 & 72.2 & 93.0 \\
\hline $\mathrm{Co}$ & 63.3 & 64.8 & 54.5 \\
\hline $\mathrm{K}$ & 26.7 & 24.9 & 15.2 \\
\hline $\mathrm{SiO}_{2}$ & 21.7 & 21.8 & 18.2 \\
\hline $\mathrm{Cd}$ & 9.73 & 9.50 & 11.0 \\
\hline $\mathrm{V}$ & 6.69 & 6.72 & 8.45 \\
\hline $\mathrm{Ni}$ & 4.56 & 4.63 & 4.59 \\
\hline $\mathrm{Ti}$ & 3.62 & 3.66 & 3.57 \\
\hline $\mathrm{Sr}$ & 1.13 & 1.15 & 1.18 \\
\hline $\mathrm{Li}$ & 0.670 & 0.479 & 0.923 \\
\hline $\mathrm{Pb}$ & $<0.5$ & 1.53 & $<0.5$ \\
\hline B & $<0.4$ & $<0.4$ & $<0.4$ \\
\hline $\mathrm{Cr}$ & $<0.4$ & $<0.4$ & 0.5 \\
\hline $\mathrm{Ba}$ & $<0.07$ & $<0.07$ & $<0.07$ \\
\hline $\mathrm{Be}$ & $<0.01$ & $<0.01$ & $<0.01$ \\
\hline $\mathrm{SO}_{4}$ & $\mathrm{n} / \mathrm{a}$ & 315000 & 333000 \\
\hline $\mathrm{F}$ & $\mathrm{n} / \mathrm{a}$ & 230 & $\mathrm{n} / \mathrm{a}$ \\
\hline $\mathrm{Cl}$ & $\mathrm{n} / \mathrm{a}$ & 1400 & $\mathrm{n} / \mathrm{a}$ \\
\hline $\mathrm{Br}$ & $\mathrm{n} / \mathrm{a}$ & $<100$ & $\mathrm{n} / \mathrm{a}$ \\
\hline $\mathrm{NO}_{3}$ & $\mathrm{n} / \mathrm{a}$ & $<200$ & $\mathrm{n} / \mathrm{a}$ \\
\hline
\end{tabular}

FA — filtered, acidified with nitric acid; FU—-filtered, unacidified; $n$ / a-not analyzed.

Although mineral samples 98CR03 and 98CR04 were collected from the same muck pile, large differences in the concentrations of some major cations are present in the pore waters extracted from these samples. The pore water compositions are similar to those of some other waters collected from the Richmond mine insofar as they are extremely acidic solutions dominated by dissolved $\mathrm{Fe}$ and sulfate. The $\mathrm{pH}$ value for both pore water samples is $-0.9 \pm 0.2$. Compared with a suite of waters collected from the Richmond mine in Septem- ber, 1990 (Nordstrom and Alpers, 1999a; Nordstrom et al., 2000), the $\mathrm{pH}$ value for the copiapite waters is lower than the values of 0.5 to 1.0 for free-flowing water in the $\mathrm{B}$ and $\mathrm{C}$ drifts but is higher than the most extreme $\mathrm{pH}$ values for waters in drips and pools associated with römerite $(\mathrm{pH}-2.5)$ and rhomboclase $(\mathrm{pH}-3.6)$. The pore waters associated with the copiapite are exceptional in that the total dissolved $\mathrm{Fe}$ is higher than that measured previously in any water sample. In particular, the concentration of $\mathrm{Fe}^{3+}$ is nearly $50 \%$ higher than values from other Richmond mine waters. Concentrations of dissolved $\mathrm{Mg}$ are 2940 to $3630 \mathrm{mg} \mathrm{L}^{-1}$, significantly higher than the 437 to $2560 \mathrm{mg} \mathrm{L}^{-1}$ for other Richmond mine waters (Nordstrom and Alpers, 1999a). The Al content of WA-98CR03 is similar to that of some of the previously reported Richmond mine waters, but that of WA-98CR04 is notably higher. The concentrations of $\mathrm{Zn}, \mathrm{Cu}, \mathrm{Cd}$, and $\mathrm{As}$ are within the range of values determined for other water samples at the mine. The density of the pore waters accompanying the copiapite-group minerals is approximately 1.5 times that of dilute aqueous solutions and is significantly greater than that of other extremely acid waters from Iron Mountain. The copiapite pore water solutions have the character of dark brown, molasses-like syrup.

A plot of $\mathrm{Mg}$ vs. Al wt.\% for copiapite-group mineral samples 98CR03 and 98CR04 and associated pore waters can be used to consider their interrelationships (Fig. 6). The straight line in Fig. 6 connects the compositions corresponding to the ideal end-member magnesiocopiapite (on the vertical axis) and aluminocopiapite (on the horizontal axis). The $\mathrm{H}_{2} \mathrm{O}-$ corrected $\mathrm{Mg}$ and $\mathrm{Al}$ concentrations for the bulk compositions A to D (Table 3) and the EPMA analyses (Table 4) of the Iron Mountain copiapitegroup minerals plot close to the line between the ideal end members, consistent with Fig. 4. The data in Fig. 6 indicate a fairly good match between the results from the wet-chemical analyses and the microprobe analyses after the $\mathrm{H}_{2} \mathrm{O}$ corrections, as was indicated in Fig. 4. The two pore water analyses differ in $\mathrm{Al}$ content, but their average $\mathrm{Al}$ and $\mathrm{Mg}$ contents are close to the composition of the microprobe points representing aluminocopiapite. This suggests that the pore water may be the mother liquor from which the aluminocopiapite has precipitated, and that it may have changed in composition from an original 


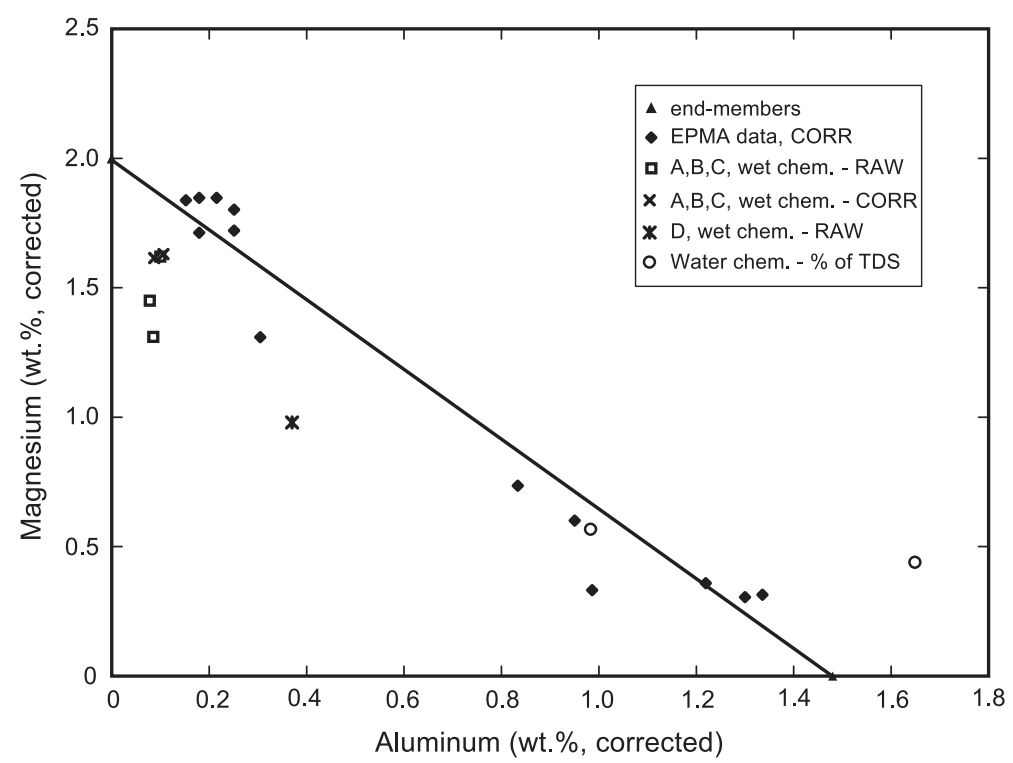

Fig. 6. Concentrations of Mg vs. Al for copiapite-group mineral samples and pore waters. The pore water compositions are plotted in terms of the relative percentage of total dissolved solids.

aqueous solution that precipitated the magnesiocopiapite. The point labeled D in Fig. 6 (plotted without $\mathrm{H}_{2} \mathrm{O}$ correction) represents the composition of a magnesiocopiapite-rich subsample that was not rinsed or dried prior to wet-chemical analysis. Point D falls between the Mg-rich samples and the pore water samples, consistent with the likelihood that it represents a mixture of magnesiocopiapite and residual Alrich solution.

\section{Discussion and conclusions}

Small grains of copiapite-group minerals are common in the underground workings of the Richmond mine, usually in association with other Fe sulfates in efflorescent encrustations on the pyrite-rich mine walls. A particularly common association is copiapite with coquimbite, voltaite, and römerite. In contrast, the material that was sampled for this study was a distinct and relatively large ( $>10 \mathrm{~L})$ concentration of damp copiapite-group minerals forming on a pile of loose, fine-grained pyrite. In this particular part of D drift, the local environmental conditions were apparently optimal for the formation of copiapite-group minerals, and the study of both the solid material and the coexisting pore water provides insight into those conditions. Given the relatively high solubility of most Fe-sulfate minerals and the seasonal changes at Iron Mountain, including significant dilution of mine waters by groundwater infiltration (Alpers et al., 1994a,b), efflorescent salts, such as the pile that was studied, are likely to be partly or completely dissolved during winter rains. The efflorescent salts commonly bloom during the dry season, as mine water of the appropriate composition evolves through processes of oxidation, evaporation, and mineral precipitation.

The conditions for precipitating copiapite are both transient and very localized. In July of 1998, only a few meters away from the magnesiocopiapite collection site, water with significantly higher $\mathrm{pH}$ values $(\sim 2)$ and lower dissolved $\mathrm{Fe}$ and $\mathrm{SO}_{4}$ concentrations than the magnesiocopiapite pore water was actively precipitating stalactites of $\mathrm{K}-\mathrm{H}_{3} \mathrm{O}$ jarosite (Robinson, 2000; Robinson et al., 2000b; Jamieson et al., in press).

The phase diagram for the $\mathrm{Fe}_{2} \mathrm{O}_{3}-\mathrm{H}_{2} \mathrm{O}-\mathrm{SO}_{3}$ system at 30-40 ${ }^{\circ} \mathrm{C}$ (Merwin and Posnjak, 1937) can be used to help understand the relationship between solution composition and mineral precipitation in highly oxidized $\mathrm{Fe}$ - and $\mathrm{SO}_{4}$-rich waters, such as those in the D drift of the Richmond mine. The principal dissolved constituents in the pore waters 
extracted from samples 98CR03 and 98CR04 are $\mathrm{Fe}^{3+}$ and $\mathrm{SO}_{4}$, in contrast to other Richmond mine waters that have lower ratios of $\mathrm{Fe}^{3+} / \mathrm{Fe}_{\text {total }}$ (Nordstrom et al., 2000; Robinson, 2000; Robinson et al., 2000b). Application of the simple ferric sulfate system to the multicomponent aqueous solution and minerals collected from the Richmond mine must be done with caution because the presence of other constituents, notably $\mathrm{Mg}, \mathrm{Al}$, and $\mathrm{Fe}^{2+}$, all of which are incorporated into the structure of copiapite-group minerals, as well as other efflorescent salts, will alter the phase relations.

Fig. 1 indicates that ferricopiapite precipitates from extremely $\mathrm{Fe}^{3+}$-rich solutions. The pore water extracted from the copiapite in this study is the most $\mathrm{Fe}^{3+}$ rich and possibly the most $\mathrm{Fe}_{\text {total }}$-rich water that has been documented from any minewaste site (Nordstrom and Alpers, 1999b). The composition of the copiapite pore water is undersaturated with respect to ferricopiapite (Fig. 1), but evaporation would cause the solution composition to move directly away from the $\mathrm{H}_{2} \mathrm{O}$ corner of the diagram along the arrow, as shown. Although Fig. 1 indicates that the solid phase expected to precipitate would be butlerite, we hypothesize that additional components, such as $\mathrm{Mg}$ and $\mathrm{Al}$, will alter the position of solubility surfaces such that the evolved solution precipitates a copiapite-group mineral. More dilute solutions in the $\mathrm{Fe}_{2} \mathrm{O}_{3}-\mathrm{H}_{2} \mathrm{O}-\mathrm{SO}_{3}$ system with similar $\mathrm{Fe} / \mathrm{S}$ ratios would be expected to precipitate hydronium jarosite, according to Fig. 1. These conditions were found in the $\mathrm{D}$ drift, where waters with lower concentrations of $\mathrm{Fe}^{3+}, \mathrm{Fe}_{\text {total }}, \mathrm{K}$, and $\mathrm{SO}_{4}$, and with higher $\mathrm{pH}$ coexist with $\mathrm{H}_{3} \mathrm{O}$-rich jarosite (Robinson, 2000; Robinson et al., 2000b). Although the water sampled in this study apparently coexists with hydronium jarosite in Fig. 1, this is a projection within a simple system and is unlikely to apply to a multicomponent system. Waters with somewhat lower dissolved $\mathrm{Fe}^{3+}$, higher $\mathrm{SO}_{4}^{2-}$, lower $\mathrm{Fe} / \mathrm{S}$ ratios, and significantly lower $\mathrm{pH}$ than those in equilibrium with copiapite-group minerals would be expected to precipitate rhomboclase, consistent with field observations elsewhere in the Richmond mine. Drip water from a rhomboclase stalactite was determined to have a $\mathrm{pH}$ of -3.6 and dissolved $\mathrm{Fe}^{3+}$ of approximately $6000 \mathrm{mg} \mathrm{L}^{-1}$ (Nordstrom and Alpers, 1999a; Nordstrom et al., 2000).
The relative stability of magnesiocopiapite and hydronium-bearing jarosite can be expressed by Reaction (1)

$$
\begin{aligned}
3 \mathrm{MgFe}_{4}{ }^{3+}\left(\mathrm{SO}_{4}\right)_{6}(\mathrm{OH})_{2} \cdot 20 \mathrm{H}_{2} \mathrm{O}+4 x \mathrm{~K}^{+} \\
\Longleftrightarrow 4\left[\mathrm{~K}_{x}\left(\mathrm{H}_{3} \mathrm{O}\right)_{1-x}\right] \mathrm{Fe}_{3}^{3+}\left(\mathrm{SO}_{4}\right)_{2}(\mathrm{OH})_{6} \\
\quad+10 \mathrm{SO}_{4}^{2-}+3 \mathrm{Mg}^{2+}+(14+4 x) \mathrm{H}^{+} \\
\quad+(38+4 x) \mathrm{H}_{2} \mathrm{O}
\end{aligned}
$$

A typical proportion of hydronium substitution for $\mathrm{K}$ in jarosite formed during weathering is 15-25 mol\% (Alpers et al., 1989; Dutrizac and Jambor, 2000; Robinson, 2000; Stoffregen et al., 2000). For $x=0.75$, Reaction (1) becomes

$$
\begin{aligned}
& 3 \mathrm{MgFe}_{4}^{3+}\left(\mathrm{SO}_{4}\right)_{6}(\mathrm{OH})_{2} \cdot 2 \mathrm{OH}_{2} \mathrm{O}+3 \mathrm{~K}^{+} \\
& \Longleftrightarrow 4\left[\mathrm{~K}_{0.75}\left(\mathrm{H}_{3} \mathrm{O}\right)_{0.25}\right] \mathrm{Fe}_{3}^{3+}\left(\mathrm{SO}_{4}\right)_{2}(\mathrm{OH})_{6} \\
& \quad+10 \mathrm{SO}_{4}^{2-}+3 \mathrm{Mg}^{2+}+17 \mathrm{H}^{+}+41 \mathrm{H}_{2} \mathrm{O}
\end{aligned}
$$

Reactions (1) and (2) are consistent with the stability of magnesiocopiapite relative to jarosite at lower $\mathrm{pH}$, which reflects the observed field relations.

Nordstrom et al. (2000) described the chemical evolution of extremely acidic mine waters at Iron Mountain as the result of four biogeochemical processes: (1) generation of acidic, ferrous sulfate solutions by pyrite oxidation, (2) concentration of ions by evaporation, (3) consumption of $\mathrm{H}^{+}$during oxidation of $\mathrm{Fe}^{2+}$ to $\mathrm{Fe}^{3+}$ (at $\mathrm{pH}<2$ and no significant hydrolysis of $\mathrm{Fe}^{3+}$, which consumes $\mathrm{OH}^{-}$), and (4) acid production or consumption during mineral precipitation, depending on the stoichiometry of the Fe sulfate precipitating. The rates of processes (1) and (3) are mediated by microbes. A combination of these factors in the D drift led to the formation of massive magnesiocopiapite. Pyrite oxidation and subsequent oxidation of $\mathrm{Fe}^{2+}$ to $\mathrm{Fe}^{3+}$ in the fluid seems to have been rapid, as no $\mathrm{Fe}^{2+}-$ sulfate minerals, such as melanterite, were observed at this location. This particularly efficient oxidation process may be influenced by the proximity of the sampling site in D drift to the ventilated area at the fiveway drift junction (Robinson, 2000). Evaporation was undoubtedly effective in concentrating $\mathrm{Fe}, \mathrm{SO}_{4}$, and other elements, as in the case of other mine waters, and was rapid enough to preclude precipitation of other ferric sulfates, such as the abundant jarosite that occurs 
only a few meters away. Process (3), oxidation of $\mathrm{Fe}^{2+}$ to $\mathrm{Fe}^{3+}$ at $\mathrm{pH}<2.2$, the $p K$ for the first hydrolysis constant of $\mathrm{Fe}^{3+}$, consumes hydrogen ions (Nordstrom and Alpers, 1999b), whereas the precipitation of magnesiocopiapite (process 4) liberates hydrogen ions:

$$
\begin{gathered}
\mathrm{Mg}^{2+}+4 \mathrm{Fe}^{3+}+6 \mathrm{SO}_{4}^{2-}+22 \mathrm{H}_{2} \mathrm{O} \Rightarrow \\
\mathrm{MgFe}_{4}^{3+}\left(\mathrm{SO}_{4}\right)_{6}(\mathrm{OH})_{2} \cdot 20 \mathrm{H}_{2} \mathrm{O}+2 \mathrm{H}^{+}
\end{gathered}
$$

The copiapite-group minerals that crystallized on the pyritiferous muck pile in the D drift consisted primarily of magnesiocopiapite, suggesting that this was the least soluble and most stable member of the copiapite group under the prevailing conditions. This interpretation assumes that equilibrium processes were dominant, and that there are no kinetic barriers to the formation of other copiapite-group minerals. Although $\mathrm{Al}, \mathrm{Ca}, \mathrm{Cu}, \mathrm{Fe}^{2+}$, and $\mathrm{Zn}$ were available in the aqueous solution, and all were incorporated to some degree in the copiapite solid solution (Tables $3-6)$, the overall composition of the larger and more abundant crystals is closest to that of the $\mathrm{Mg}$ end member. At some point, conditions changed such that aluminocopiapite became the stable crystalline phase and precipitated as spheroidal aggregates on the magnesiocopiapite plates (Fig. 2). The textural relations suggest that there was a hiatus in mineral precipitation and a distinct change of conditions. Given that mutual substitution of $\mathrm{Mg}-\mathrm{Al}-\mathrm{Fe}^{2+}-\mathrm{Fe}^{3+}$ is considered to be complete (Jambor et al., 2000), a gradual change of conditions would have been expected to produce a gradual change in the composition of the equilibrium copiapite rather than two distinct morphologies and compositions. This change in fluid composition may not have been gradual and may have occurred in the mine or during the 3-week period of storage before most of the pore water was extracted by centrifuge, or the aluminocopiapite may have formed from the small amount of fluid left after centrifuging and in contact with the sample during several months of storage in the incubator. Formation of the aluminocopiapite during drying of the samples in preparation for SEM and other analytical work is unlikely because the XRD trace of the damp material as taken directly from the bottle (though not immediately after collection) indicated that both copiapite-group minerals were already present, and the mineral that consistently formed during sample air-drying was coquimbite.

The results of this study have shown that it is possible to microanalyze fragile and sensitive hydrated Fe-sulfate minerals, such as copiapite-group minerals, that are prone to deliquescence and dehydration during storage. Some postsampling changes may be unavoidable, but if samples are examined carefully at every step in the analytical procedure, these changes can be documented. The composition of the two copiapitegroup minerals provides insight into the relative stability of members of this mineral group and the coexisting fluid. The composition of the pore water coexisting with the copiapite-group minerals is consistent with known phase relations in the $\mathrm{Fe}_{2} \mathrm{O}_{3}-\mathrm{H}_{2} \mathrm{O}-$ $\mathrm{SO}_{3}$ system and with the processes involved in the chemical evolution of acid mine waters. Although the copiapite samples described in this study are from an unusually large, quasi-monomineralic accumulation, copiapite-group minerals coexist with other hydrous Fe sulfates elsewhere in the Richmond mine. Like other relatively soluble $\mathrm{Fe}$ sulfates, copiapite-group minerals provide temporary storage of $\mathrm{Fe}$ and $\mathrm{SO}_{4}$. Unlike melanterite, voltaite, and szomolnokite (Jamieson et al., 1999), however, the storage of potentially hazardous elements, such as $\mathrm{Zn}, \mathrm{Cu}$, $\mathrm{As}$, and $\mathrm{Cd}$, in copiapite-group minerals is relatively modest in the samples that have been examined. Release of $\mathrm{Fe}^{3+}$ through dissolution of copiapite-group minerals would provide additional oxidant for further pyrite oxidation even if the mine workings were flooded and oxygen excluded (Nordstrom and Alpers, 1999a; Jamieson et al., 1999).

\section{Acknowledgements}

Funding for this research was provided in part from NSERC grants to HEJ. HEJ and CR thank G. Laflamme at CANMET for carefully preparing the copiapite polished section and J.L. Campbell and Z. Nejedly at the University of Guelph for help with the micro-PIXE analysis. D.M. Carmichael, P.L. Roeder, and S.R. Brown at Queen's University provided useful advice on early stages of the research. M.P. Hunerlach at the USGS, Sacramento, assisted with the field and laboratory work. J.M. Neil assisted with x-ray diffraction at the University of California. R.B. McCleskey 
and D.K. Nordstrom acknowledge the support of the USGS National Research Program, Water Resources Discipline. All of the authors are grateful to the personnel of Region 9 of the USEPA, especially the Project Site Manager, Rick Sugarek, for facilitating mine access and providing funding for a portion of this research. The use of brand names and trademarks in this paper is for identification purposes and does not constitute endorsement by the U.S. Geological Survey. [PD]

\section{References}

Alpers, C.N., Nordstrom, D.K., 1999. Geochemical modeling of water-rock interactions in mining environments. In: Plumlee, G.S., Logsdon, M.J. (Eds.), The Environmental Geochemistry of Mineral Deposits: Part A. Processes, Techniques, and Health Issues, Rev. Econ. Geol., vol. 6A, pp. 289-323.

Alpers, C.N., Nordstrom, D.K., Ball, J.W., 1989. Solubility of jarosite solid solutions precipitated from acid mine waters, Iron Mountain, California, USA. Sci. Géol., Bull. 42, 281-298.

Alpers, C.N., Nordstrom, D.K., Burchard, J.M., 1992. Compilation and interpretation of water-quality and discharge data for acidic mine waters at Iron Mountain, Shasta County, California, 1940 91. U.S. Geol. Surv. Water-Resour. Investig. Rep. 91-4160.

Alpers, C.N., Nordstrom, D.K., Thompson, J.M., 1994a. Seasonal variations of $\mathrm{Zn} / \mathrm{Cu}$ ratios in acid mine water from Iron Mountain, California. In: Alpers, C.N., Blowes, D.W. (Eds.), Environmental Geochemistry of Sulfide Oxidation, Am. Chem. Soc. Symp. Ser., vol. 550, pp. 324-344.

Alpers, C.N., Blowes, D.W., Nordstrom, D.K., Jambor, J.L., 1994b. Secondary minerals and acid mine-water chemistry. In: Jambor, J.L., Blowes, D.W. (Eds.), Environmental Geochemistry of Sulfide Mine-Wastes, Short Course-Mineral. Assoc. Can., vol. 22, pp. 247-270.

Alpers, C.N., Nordstrom, D.K., Spitzley, J., 2003. Extreme acid mine drainage from a pyritic massive sulfide deposit: the Iron Mountain end-member. In: Jambor, J.L., Blowes, D.W., Ritchie, A.I.M. (Eds.), Environmental Aspects of Mine Wastes, Short Course-Mineral. Assoc. Can., vol. 31, pp. 407-430.

Bandy, M.C., 1938. Mineralogy of three sulphate deposits of northern Chile. Am. Mineral. 23, 669-760.

Bayless, E.R., Olyphant, G.A., 1993. Acid-generating salts and their relationship to the chemistry of groundwater and storm runoff at an abandoned mine site in southwestern Indiana, USA. J. Contam. Hydrol. 12, 313-328.

Bayliss, P., Atencio, D., 1985. X-ray powder-diffraction data and cell parameters for copiapite-group minerals. Can. Mineral. 23, $53-56$.

Berry, L.G., 1947. Composition and optics of copiapite. Univ. Tor. Stud. Contrib. Can. Mineral. 51, 21-34.

Brinton, T.I., Antweiler, R.C., Taylor, H.E., 1996. Method for the determination of dissolved chloride, nitrate and sulfate in natural water using ion chromatography. U.S. Geol. Surv. Open-File 95-426.

Cabri, L.J., Campbell, J.L., 1998. The proton microprobe in ore mineralogy (micro-PIXE technique). In: Cabri, L.J. (Ed.), Modern Approaches to Ore and Environmental Mineralogy, Short Course-Mineral. Assoc. Can., vol. 27, pp. 181-198.

Cravotta III, C.A., 1994. Secondary iron-sulfate minerals as sources of sulfate and acidity. In: Alpers, C.N., Blowes, D.W. (Eds.), Environmental Geochemistry of Sulfide Oxidation, Am. Chem. Soc. Symp. Ser., vol. 550, pp. 345-364.

Dutrizac, J.E., Jambor, J.L., 2000. Jarosites and their application in hydrometallurgy. In: Alpers, C.N., Jambor, J.L., Nordstrom, D.K. (Eds.), Sulfate Minerals - Crystallography, Geochemistry and Environmental Significance, Rev. Mineral. Geochem., vol. 40 , pp. $405-452$.

Dutrizac, J.E., Jambor, J.L., Chen, T.T., 1987. The behaviour of arsenic during jarosite precipitation: reactions at $150{ }^{\circ} \mathrm{C}$ and the mechanism of arsenic precipitation. Can. Metall. Q. 26, $103-115$.

Edwards, K.J., Bond, P.L., Gihring, T.M., Banfield, J.F., 2000. An archaeal iron-oxidizing extreme acidophile important in acid mine drainage. Science 287, 1796-1799.

Fanfani, L., Nunzi, A., Zanazzi, P.F., Zanzari, A.R., 1973. The copiapite problem: the crystal structure of a ferrian copiapite. Am. Mineral. 58, 314-322.

Fang, J.H., Robinson, P.D., 1970. Crystal structures and mineral chemistry of hydrated ferric sulfates: 1 . The crystal structure of coquimbite. Am. Mineral. 55, 1534-1540.

Goldstein, J.I., Newbury, D.E., Echlin, P., Joy, D.C., Romig Jr., A.D., Lyman, C.E., et al., 1992. Scanning Electron Microscopy and X-ray Microanalysis. (2nd ed). Plenum Press, New York.

Haidinger, W., 1845. Handbuch der bestimennden Mineralogie (Vienna).

Hawthorne, F.C., Krivovichev, S.V., Burns, P.C., 2000. The crystal chemistry of sulfate minerals. In: Alpers, C.N., Jambor, J.L., Nordstrom, D.K. (Eds.), Sulfate Minerals - Crystallography, Geochemistry and Environmental Significance, Rev. Mineral. Geochem., vol. 40, pp. 1-112.

Hay, D., 1995. Celsiz Version 1.1 (computer program). CSIRO, Clayton, Australia.

Jambor, J.L., 1994. Mineralogy of sulfide-rich tailings and their oxidation products. In: Jambor, J.L., Blowes, D.W. (Eds.), Environmental Geochemistry of Sulfide Mine-Wastes, Short Course-Mineral. Assoc. Can. vol., 22, pp. 59-102.

Jambor, J.L., Nordstrom, D.K., Alpers, C.N., 2000. Metal-sulfate salts from sulfide mineral oxidation. In: Alpers, C.N., Jambor, J.L., Nordstrom, D.K. (Eds.), Sulfate Minerals-Crystallography, Geochemistry and Environmental Significance, Rev. Mineral. Geochem., vol. 40, pp. 303-350.

Jamieson, H.E., Pryzbylowicz, W., 1997. The incorporation of toxic elements in iron sulfates precipitated from acid mine waters. Geol. Assoc. Can.-Mineral. Assoc. Can. Program Abstr. 22, A73.

Jamieson, H.E., Alpers, C.N., Nordstrom, D.K., Peterson, R.C., 1999. Substitution of zinc and other metals in iron sulfate minerals at Iron Mountain, California. In: Goldsack, D., Belzile, N., Yearwood, P., Hall, G. (Eds.), Sudbury '99, Mining 
and the Environment: II, vol. 1. Laurentian Univ., Sudbury, Ontario pp. 231-241.

Jamieson, H.E., Robinson, C., Alpers, C.N., Nordstrom, D.K., Poustovetov, A., in press. The composition of co-existing jarosite and water from the Richmond mine, Iron Mountain, California. Can. Mineral.

JCPDS (Joint Committee on Powder Diffraction Standards), 1997. Mineral Powder Diffraction File. International Centre for Diffraction Data, Swarthmore, Pennsylvania.

Kinkel, A.R., Hall, W.E., Albers, J.P., 1956. Geology and basemetal deposits of West Shasta copper-zinc district, Shasta County, California. U. S. Geol. Surv. Prof. Pap. 285, 13-18.

Krumm, S., 1997. WinFit. Univ. Erlangen, Erlangen, Germany.

Mandarino, J.A., 1999. Fleischer's Glossary of Mineral Species. Mineralogical Record, Tucson, Arizona.

McCaughey, W.J., 1917. Copiapite in coal. Am. Mineral. 3, $162-163$.

Merwin, H.E., Posnjak, E., 1937. Sulfate incrustations in the Copper Queen Mine, Bisbee, Arizona. Am. Mineral. 22, 567-571.

Munsell Color, 1954. Munsell ${ }^{\circledR}$ Soil Color Charts. Munsell Color Gretag MacBeth (New Windsor, New York).

Nordstrom, D.K., 1982. Aqueous pyrite oxidation and the consequent formation of secondary iron minerals. In: Kittrick, J.A., Fanning, D.S., Hossner, L.R. (Eds.), Acid Sulfate Weathering, Soil Sci. Soc. Am. Spec. Publ., vol. 10, pp. 37-46.

Nordstrom, D.K., Alpers, C.N., 1995. Remedial investigations, decisions, and the geochemical consequences at Iron Mountain mine, California. In: Hynes, T.P., Blanchette, M.C. (Eds.), Sudbury '95, Mining and the Environment, vol. 2. CANMET, Natural Resources Canada, Ottawa, pp. 633-642.

Nordstrom, D.K., Alpers, C.N., 1999a. Negative pH, efflorescent mineralogy, and consequences for environment restoration at the Iron Mountain Superfund site, California. Proc. Natl. Acad. Sci. U.S.A. $96,3455-3462$.

Nordstrom, D.K., Alpers, C.N., 1999b. Geochemistry of acid mine waters. In: Plumlee, G.S., Logsdon, M.J. (Eds.), The Environmental Geochemistry of Mineral Deposits: Part A. Processes, Techniques, and Health Issues, Rev. Econ. Geol., vol. 6 A, pp. $133-160$.

Nordstrom, D.K., Alpers, C.N., Ptacek, C.J., Blowes, D.W., 2000. Negative $\mathrm{pH}$ and extremely acidic mine waters from Iron Mountain, California. Environ. Sci. Technol. 34, 254-258.

Palache, C., Berman, H., Frondel, C., 1951. (7th ed.). The System of Mineralogy, vol. 2. Wiley, New York.

Perroud, P., Messier, N., Sarp, H., 1987. Presence of zincocopiapite at Valai, Schweiz. Mineral. Petrogr. Mitt. 67, 155-177 (in French).

Plummer, L.N., Parkhurst, D.L., Fleming, G.W., Dunkle, S.A., 1988. A computer program incorporating Pitzer's equations for calculation of geochemical reactions in brines. U.S. Geol. Surv. Water-Resour. Investig. Rep. 88-4153.
Posnjak, E., Merwin, H.E., 1922. The system, $\mathrm{Fe}_{2} \mathrm{O}_{3}-\mathrm{SO}_{3}-\mathrm{H}_{2} \mathrm{O}$. J. Am. Chem. Soc. 44, 1965-1994.

Robbins, E.I., Rodgers, T.M., Alpers, C.N., Nordstrom, D.K., 2000. Ecogeochemistry of the subsurface food web at $\mathrm{pH} 0-2.5$ in Iron Mountain, California, USA. Hydrobiologia 433, 15-23.

Robinson, C., 2000. The role of jarosite and copiapite in the chemical evolution of acid drainage waters, Richmond Mine, Iron Mountain, California. MS thesis, Queen's Univ., Kingston, Canada.

Robinson, C., Jamieson, H.E., Peterson, R.C., Alpers, C.N., Nordstrom, D.K., 2000a. Major and trace element composition of copiapite from the Richmond mine, Iron Mountain, CA. Abs. Programs-Geol. Soc. Am. 32 (7), A110.

Robinson, C., Jamieson, H.E., Alpers, C.N., Nordstrom, D.K., 2000b. The composition of co-existing jarosite and water from the Richmond mine, Iron Mountain, CA. Abstr. Programs-Geol. Soc. Am. 32 (7), A101.

Rose, G., 1833. Ueber einige in Sudamerika vorkommende Eisenoxydsalze. Ann. Phys. 27, 309-319.

Savage, K.S., Bird, D.K., O’Day, P.A., 2005. Arsenic speciation in synthetic jarosite. Chem. Geol. 215, 473-498 (this issue).

Stanley, C.J., Laflamme, J.H.G., 1998. Preparation of specimens for advanced ore-mineral and environmental studies. In: Cabri, L.J. (Ed.), Modern Approaches to Ore and Environmental Mineralogy, Short Course-Mineral. Assoc. Can., vol. 27, pp. 111-121.

Stoffregen, R.E., Alpers, C.N., 1987. Woodhouseite and svanbergite in hydrothermal ore deposits: products of apatite destruction during advanced argillic alteration. Can. Mineral. 25, 201-211.

Stoffregen, R.E., Alpers, C.N., Jambor, J.L., 2000. Alunite-jarosite crystallography, thermodynamics, and geochronology. In: Alpers, C.N., Jambor, J.L., Nordstrom, D.K. (Eds.), Sulfate Minerals - Crystallography, Geochemistry, and Environmental Significance, Rev. Mineral. Geochem., vol. 40, pp. 453-479.

Stookey, L.L., 1970. FerroZine-a new spectrophotometric reagent for iron. Anal. Chem. 42, 779-781.

Süsse, P., 1972. Crystal structure and hydrogen bonding of copiapite. Z. Krystallogr. 135, 34-55.

To, T.B., Nordstrom, D.K., Cunningham, K.M., Ball, J.W., McCleskey, R.B., 1999. New method for the direct determination of $\mathrm{Fe}(\mathrm{III})$ concentration in acid mine waters. Environ. Sci. Technol. 33, 807-813.

Waller, R., 1992. Temperature and humidity sensitive mineralogical and petrological specimens. In: Howie, F.M. (Ed.), The Care and Conservation of Geological Material: Minerals, Rocks, Meteorites, and Lunar Finds. Butterworth-Heinemann, Oxford, UK, pp. 29-50.

Zodrow, E.L., 1980. Hydrated sulfates from Sydney Coalfield, Cape Breton Island, Nova Scotia, Canada: the copiapite group. Am. Mineral. 65, 961-967. 